\title{
Systematical and biochronological review of Plio-Pleistocene Alceini (Cervidae; Mammalia) from Eurasia
}

\author{
Marzia Breda $^{\mathrm{a}, \mathrm{b}, *}$, Marco Marchetti ${ }^{\mathrm{a}}$ \\ ${ }^{a}$ Dipartimento delle Risorse Naturali e Culturali, Universitá di Ferrara, Corso Porta Mare 2, 44100 Ferrara, Italy \\ ${ }^{\mathrm{b}}$ Dipartimento di Geologia, Paleontologia e Geofisica, Universitá di Padova, Via Giotto 1, 35100 Padova
}

Received 18 December 2002; accepted 28 May 2004

\begin{abstract}
Systematics, taxonomy and phylogeny of Eurasian fossil moose are discussed in order to analyse their distribution in space and time. The largest European collections were studied. We recognise the genus Cervalces, including the chronospecies $C$. gallicus, $C$. carnutorum and C. latifrons, as well as the genus Alces, with the species A. alces. Cervalces differs from Alces in the facial area, in the length of the antlers and in the orientation of the palmation. Taking into account as more bibliography as possible, we suggest that the Siberian remains, due to their distance from the type localities, have size ranges and beam proportions a little different from the coeval European ones, so they are regarded as different geographic populations. Cervalces latifrons postremus systematics and chronology have been reconsidered. It results that it was present only in Siberia during the penultimate glaciation and was of the same body size as typical $C$. latifrons. It is likely that $A$. alces is not the direct descendant of the last European Cervalces, but its origin is still an open question. The present analysis provides a clearer picture of the geographical and chronological distribution of Cervalces and Alces.
\end{abstract}

(C) 2004 Elsevier Ltd. All rights reserved.

\section{Introduction}

The Alceini tribe is a well-characterised group of deer of as yet unclear origin. The Alceini separated from other deer probably in the Upper Miocene (Kahlke, 1990), but no remains from the Cervalces lineage from the period prior to the Middle Pliocene have been found so far. Recent molecular results confirm the isolated position of the Alceini, suggesting that they are the sister-group of the clade Capreolini + Hydropotini (Cronin et al., 1996; Randi et al., 1998).

The fossil Alceini have been studied thoroughly, but there is no agreement on their taxonomy and the phylogenetic relationships among their member taxa, due to a lack of consensus on which characters should hold a determining value (Breda, 2001a). Although dispersed over a wide geographical area in the Holoarc-

\footnotetext{
${ }^{*}$ Corresponding author. Dipartimento delle Risorse Naturali e Culturali, Universitá di Ferrara, Corso Porta Mare 2, 44100, Ferrara.

E-mail address: marziabreda@hotmail.com (M. Breda).
}

tic Region since the Late Pliocene, the Alceini group is difficult to study today because remains are typically few and sparsely distributed, as the social organisation of these animals was probably non-gregarious (Breda, 2001a, 2002).

Issues of classification within the Alceini tribe are disputed both at the generic and specific level. Today there is disagreement on the number of genera and species to be considered, the generic allocation of these species and their interrelationships. The present work aims to provide additional information on the natural history of the Alceini tribe through the most complete revision possible of its systematics, taxonomy, phylogeny and distribution in time and space throughout Plio-Pleistocene in Eurasia.

\section{Systematics, taxonomy and phylogeny}

Prior to consider the biochronologic section, the specifics of the taxonomy that will be followed in the 
text is given, focusing on problems specific to the Alceini group and explaining the reasoning behind our choices.

\subsection{Generic distinction between Alces and Cervalces}

At present, many authors put the fossil moose species in Cervalces and the only living species in Alces (Azzaroli, 1979, 1982, 1985, 1994; Vislobokova, 1986; Sher, 1987; Churcher and Pinsof, 1987; Churcher, 1991; Breda, 2001a,b), while others recognise Alces as the only genus (Heintz and Poplin, 1981; Geraads, 1983; Lister, 1987, 1993a, b, 1996; Kahlke, 1990, 1995, 1997; Pfeiffer, 1999a; Guérin et al., 2003). Lister (1993a) recognises that the Cervalces species are phenetically more similar to each other than to the modern moose Alces alces (Linneus, 1758). Nonetheless, he places all species in the genus Alces, as it is difficult to arrive at a reliable generic subdivision for the intermediate forms for which no skulls have been found so far. Furthermore, he points out that "the characters on which the Cervalces species are united are largely primitive ones".

We prefer to retain two genera, due to important morphological characters distinguishing them. The genus Alces, represented by the only species A. alces, shows some apomorphies, such as the narrow and deep occipital (Azzaroli, 1979) and the short nasals which are not articulated to the very long premaxillaries (Azzaroli, 1952). Of these two characters, the facial structure bears a higher value than the occipital bone, because the insertion surface for the powerful neck muscles varies with head weight and thus with antler size.

Nonetheless, the contact between nasals and praemaxillaries was sometimes present also in the Caucasian sub-fossil subspecies, A. alces caucasicus (Vereshchagin, 1955), and, as an exception, in some recent European moose (e.g. a specimen recorded by Pfeiffer (1999a) and another by Lister (2004)). In any case, the contact is much less developed in Alces than in Cervalces and does not imply the long nasals and short praemaxillaries of the latter.

One of the main universally recognised differences between Cervalces and Alces is the much shorter antler beam in the latter (Azzaroli, 1952; Lister 1987, 1993a, b). Some authors (Sher, 1974; Lister, 1993b), attempted to codify this shortening by indexes. Sher (1974) considers the "index of massivness", consisting of the beam circumference divided by its length, $\times 100$, and suggests that this index should give values higher than $100 \%$ in A. alces, and lower in Cervalces. Lister (1993b), on the contrary, considers the rate between the beam length and its circumference. He constructs a graph to show the dependence of the proportions of the antler beam from the stratigraphic age, in which the wide superposition between Cervalces and A. alces is evident, even if the shortening is undeniable. Moreover, Lister (1993b,c) tries to correct the effect of the onthogenetic growth by excluding the juvenile antlers, yet he arbitrarily designates as juvenile the antlers with beam circumference smaller than 175 and $150 \mathrm{~cm}$ for Cervalces latifrons and A. alces, respectively. We make use of the same kind of graph (utilised also by Pfeiffer (1999a), Nikolskiy and Titov (2002) and Boeskorov (2002)) to identify the antler remains. However, unless other diagnostic remains are present from the same locality, we consider specimens close to the limits of the ranges of the two genera non-identifiable with certainty. Moreover, because beam shortening is present along the entire Cervalces line, its diagnostic value at genus level is questionable.

Boeskorov (2002) maintains that a further distinction between Cervalces and Alces lies in the morphology of the frontals that, in the extinct genus, should have a "considerably smaller eminence between antlers". This is in agreement with the suggestion by Scott (1885) that a bulge between pedicles is typical of living moose while it is missing in the skull of the North American Cervalces scotti (Lydekker, 1898), the type-species of the genus Cervalces. Actually, there is a wide range of variability in the development of the bulge both in Alces and Cervalces (Breda, 2001a), thus this character cannot bear any diagnostic value. This is confirmed by Pfeiffer (1999a, 2002), who claims, in contrast to Boeskorov and Scott, that in $C$. latifrons the frontals, between the pedicles, are reinforced in their transverse section, building a bony bridge to balance the big lateral extension of antlers, and that this reinforcement is missing in A. alces. Bubenik (1998) suggests that, in living moose, the bony proliferation constituting the bulge is stimulated by the repeated shocks that the animal bears competing with other males, during rutting season.

We suggest instead, that for a generic subdivision of the tribe the orientation of the palmation plane of the antlers is more important. As already suggested by Hennig (1952) and pointed out by Breda (2001b), in the fossil genus the palmation plane is about vertical (perpendicular to the frontal bones), with a little posterior concavity, while in the living species it is horizontal (parallel to the frontal bones), with a good upper concavity.

\subsection{The species of Cervalces}

In the genus Cervalces Scott (1885), described on the North American type species C. scotti (Lydekker, 1898) from the Late Pleistocene, we consider the Eurasian forms Cervalces gallicus (Azzaroli, 1952), Cervalces carnutorum (Laugel, 1862) and C. latifrons (Johnson, $1874)$ as valid. Whereas all authors recognise the Late Pliocene species $C$. gallicus and its predominantly Middle Pleistocene descendant $C$. latifrons, the validity of the species $C$. carnutorum, of intermediate geological 
age, is still unclear (Pfeiffer, 1999a; Breda 2001a). Some authors (Vislobokova, 1986; Sher, 1987; Lister, 1993b; Pfeiffer, 1999a) do not recognise the species $C$. carnutorum and assign these remains alternatively to C. gallicus and to C. latifrons. Other authors (Geraads, 1983; Boeuf et al., 1992) combine $C$. latifrons and $C$. carnutorum in a single species, resolving the synonymy in favour of the latter because of its historical priority. This fact generated confusion in literature. Thus, until more informative remains become available, we prefer to follow Heintz and Poplin (1981), Kahlke (1990, 1995), Kahlke $(1999,2000)$ and Guérin et al. (2003) in using the species $C$. carnutorum, to avoid adding to the ambiguity in nomenclature (Breda, 2001b).

Morphological analysis of the dental, cranial and postcranial elements (Breda, 2001b, 2004) revealed that the three Eurasian Cervalces species do not posses specific characters enabling identification on morphological ground only. They can be considered chronospecies of the same phyletic lineage which underwent a gradual, or so considered by most authors, increase in body size from $C$. gallicus through the intermediate $C$. carnutorum, to C. latifrons, as predicted by the Cope's rule. A quantification of this size variation, or at least its increase in the Cervalces line, is difficult to accomplish because the remains are few and fragmentary (Breda, 2001b). Mosbach ${ }^{(20)}$ (the number in superscript refers to Appendix Table A1 where the geographic indications are given for each locality) is the only European locality that yielded abundant Cervalces remains, but these are not useful for size comparisons because they were collected without recording the stratigraphical horizon. There are two levels present at Mosbach. One is comparable in age to other European sites with $C$. latifrons and the other to European sites with $C$. carnutorum. Therefore a reliable and specific identification of the Cervalces remains from this locality is not possible (Breda, 2004).

The same explanation of "anagenetic" evolution within the Cervalces line is usually put forward for the "gradual" modelling of antlers, due to the progressive shortening of beams. Although the shortening of the beam is undeniably present, it is also highly variable and heavily influenced by the level of individual ontogenetic development. Vos and Mol (1997) and Pfeiffer (1999a) point out that an accurate definition of the measured values is difficult and results in a large measuring error. Pfeiffer (1999a) suggests that, since the dimensions of the antlers overlap among moose species, a taxonomical allocation on the basis of this parameter is difficult. However, if a sufficient number of antlers from a same locality is present, a taxonomical allocation can be attempted. As already assessed for the value of the indexes and the graphs for distinguishing Alces and Cervalces, we consider that they are useful for the taxonomic identification of the majority of antlers that are on the opposite ends of the full range. However, all those antlers that lie close to the boundaries between two species can be identified only tentatively.

Because of the definition of chronospecies, the limits among the Cervalces species are arbitrary. The problem is not restricted to the only $C$. carnutorum. Although better records are available and the species are on the opposite ends of the range for the Cervalces phyletic line, the validity of the distinction between $C$. gallicus and $C$. latifrons could be questioned on the same bases. In fact, there is no morphological variation between the skeletons of the two species, except for some presumed features of the occipital condyles, which are partly dependent on the age and sex of the specimen and, thus, have limited taxonomic value (Breda, 2001a). With respect to the body size, the increase from $C$. gallicus through $C$. carnutorum to $C$. latifrons is undeniable. However the distribution of body size for the three species and the width of overlap between them are unknown.

In fact, there are no limb bones available for $C$. gallicus from western Europe, except for those of the holotype from Senèze ${ }^{(3)}$ (Azzaroli, 1952), consisting of an adult male with partial antlers and the complete skeleton, mounted but showing heavy damages in all its elements. Azzaroli (1952) described also a cotype, from the same locality, composed of the limb bones of a stronger specimen, which is in far better conditions. The body size range of $C$. gallicus has been based on these two skeletons until the limb bones of the second specimen were attributed to the holotype by Breda (2001a). The previously assembled limb bones can be determined only at the family level due to their bad state of preservation. Thus the size estimate for the species now rests on only one specimen which has a very limited value. Furthermore, this leads to an even smaller difference in size between C. gallicus and C. latifrons than formerly thought, as the skeleton considered is the larger one of the two from Senèze.

For C. latifrons, only few isolated bone remains are known from the Middle Pleistocene localities since the Mosbach $^{(20)}$ collection cannot be fully considered, as explained above. Among these bones there are size differences implying that population variability is very wide and, consequently, that size is not a good systematic criterion. In particular, the moose remains from Süssenborn ${ }^{(40)}$ and Voigtstedt m.l. ${ }^{(22)}$ (m.l. = middle level) are the largest and those from Mauer ${ }^{(43)}$ the smallest, with little overlap between them (Mosbach remains are in the middle). Only the specimens at the boundaries of the size ranges (i.e. the smallest $C$. gallicus and the largest $C$. latifrons) can be identified with certainty, while all the isolated remains of intermediate size cannot. 


\subsection{The transition between $C$. latifrons and A. alces}

While reaching a taxonomical consensus on the Cervalces lineage is difficult, its relationship with the living $A$. alces is even more controversial. The traditional argument views $C$. latifrons evolving into $A$. alces by a gradual shortening of the antler beam and a decrease in body size. Lister (1987, 1993b) suggests that the reduction in antler beam length could have been the response to the passage from a more open habitat, in which outstretched antlers may have been ideal display organs, to a forested one in which large antler span could have impeded movement. However, the open Taiga forest, that constitutes the large part of today's moose habitat, would also be habitable for Cervalces. Moreover convincing palynological (Breda et al., 2004) and faunal evidence suggests that Cervalces could have lived in habitats analogous to those of the living moose.

As for the reduction in size from $C$. latifrons to $A$. alces, Geist (1999) suggests that this trend could have had an adaptive advantage in an environment with limited resources. Pfeiffer (1999a, 2002) maintains that the width mass range of the metapodia of both taxa are so clearly separated from each other that a gradual transition between $C$. latifrons and the living A. alces is not likely. A reduction in size did occur, but it was not prominent and there is partial overlap between the size ranges of the two species. In fact, there is a wide variation in size both in the subspecies of living moose (e.g. the east Siberian A. a. pfizenmayeri and the Alaskan $A$. a. gigas are very large) and the various $C$. latifrons populations (e.g. the remains from Mauer and from Vergranne $^{(36)}$ are very small).

Kahlke (1990) suggests that the last populations of $C$. latifrons underwent gradual dwarfing (identified by Kahlke in the subspecies C. latifrons postremus) and survived in the northern parts of Eurasia and North America to be finally replaced by the present $A$. alces. $C$. latifrons postremus was described by Vangengeim and Flerow (1965) on a fragment of a shed antler from Mamontova Gora ${ }^{(86)}$, with a beam intermediate in length and diameter between $C$. latifrons and A. alces. This subspecies, later recorded in Alaska and Canada (Kahlke, 1990) and in Europe (Kahlke, 1975a, 1976; Koenigswald and Menger, 1997), has been considered intermediate in size between $C$. latifrons and A. alces (Sher, 1974; Kahlke, 1990; Boeskorov, 2002; Nikolskiy and Titov, 2002). To date, cranial remains including the occipital or facial regions to allow a taxonomical positioning (i.e. generic allocation) are still lacking (Sher, 1987; Breda, 2001a). Pfeiffer (1999a) suggests that the European antlers attributed to $C$. latifrons postremus belong to young specimens of $C$. latifrons and that this subspecies has no meaning, as the $C$. latifrons remains from early Middle Pleistocene are not different neither in morphology nor size. In fact, in Europe, the only postcranial and teeth remains identified as $C$. latifrons postremus are from Ehringsdorf ${ }^{(48)}$ (Kahlke, 1975a) and fall within the size range of the C. latifrons from Mosbach (Heintz and Poplin, 1981). Recently Boeskorov (2002) described a partial antler with the frontal bone of $C$. latifrons postremus from Verkhnevilyuiskoe ${ }^{(76)}$, maintaining it belongs to the genus Cervalces because of the width of the frontal bone and of the absence of the frontal eminence between pedicles. As already explained in the discussion of the difference between Alces and Cervalces, the presence/absence of the frontal eminence has no diagnostic value because it is very variable in both the genera. Boeskorov (2002) maintains also that "the size of the antler beams of the late broad-fronted moose is much smaller than those of C. latifrons, almost no overlap is observed" and maintains that it has to be considered as an independent species rather than a subspecies of $C$. latifrons, because of the temporal discontinuity between them (the specific rank having already been suggested by Sher (1987)).

The beam shortening in $A$. alces in comparison with C. latifrons is evident but, as already explained, this is a highly variable feature and the difference which justifies the generic division involves, rather, the orientation of the palmation plane. If the evolution from $C$. latifrons to $A$. alces had been gradual through the intermediate $C$. latifrons postremus, as maintained by Kahlke (1990), the antlers of the last should show both an intermediate beam length and palmation plane rotation. Indeed, the European remains (from Ehringsdorf and the Upper Rhine Valley ${ }^{(40)}$ ) designated as C. latifrons postremus, although poorly preserved, exhibit the same morphology as those of C. latifrons (Breda, 2001b). The only one specimens from Siberia with both the antler and the frontal bone is the one found in Verkhnevilyuiskoe described by Boeskorov (2002). However, on this the origin of the antler palmation is missing, making it impossible to verify the rotation of the palmation plane.

Since citations of European specimens of $C$. latifrons postremus are rare, their discussion will be deferred to Section 7, following the analysis of the more abundant Siberian material.

At present, most researchers believe that $A$. alces is on a different phyletic line (Sher, 1987; Kahlke, 1990; Pfeiffer 1999a, 2002; Breda, 2001a, b). Kahlke suggests Alces brevirostris Kretzoi, 1944, as possible ancestor of modern moose, while Sher (1987) proposes Alces savinus (Fisher, 1830).

A. brevirostris is represented only by the holotype consisting of a fairly complete skeleton of an adult male, from Ördöglyuck cave ${ }^{(57)}$, described but not published by Kretzoi. Jánossy (1969) reports the original description by Kretzoi for the cranium and a picture of the left antler, both destroyed in a fire along with the jaw. The premaxillaries were notably shorter and the nasals oneand-a-half to nearly twice as long as in $A$. alces, but 
there is no mention of a connection between them, as typical in $A$. alces and the structure of the occipital region was not described. Vörös (1985) reports that $A$. brevirostris had strong diaphysis of the long bones (again a feature of Cervalces), but its size was within the lower end of the range of living moose and thus very different from $C$. latifrons. Moreover, the antlers resemble those of $A$. alces ones for the short beam and the structure of the palmation. With only a single individual available, we cannot state whether it represents a distinct species or a teratological specimen. The only still available data, that is the antler proportions and the small post-cranial bones, permit an attribution to cf. Alces sp.

Cervus savinus was described based on a male skull from Routa River ${ }^{(61)}$, and was later transferred to the genus Alces by Rouiller (1847). Pavlow (1906) suggests that $A$. savinus may be a species intermediate between $A$. latifrons and Alces palmatus $(=$ A. alces) due to its long beams and assigns to it a skull from Missa ${ }^{(62)}$ (= Misy). In the description by Rouiller (1847) we find some characters of $A$. savinus that are close to those of the genus Cervalces including the large body size and an occipital bone lower and larger than those of other skulls used for comparison. In this analysis we consider $A$. savinus synonymous with $A$. alces, since the measurements by Rouiller are consistent with the latter. Furthermore, the antlers have very short beams and a cup-like palmation and the facial portion has short nasals not in contact with the long praemaxillaries as in living moose and in the skull from Missa. The hypothesis by Pavlow that the holotype of $A$. savinus had long antler beams is based on a mistaken reading of the measurements by Rouiller.

\section{Preliminary considerations to the biochronological chapters}

Breda studied on her own the Cervalces remains from Italy, the $C$. gallicus holotype from Senèze (University of Lyon), the Cervalces from the English Cromer Forest Bed (Natural History Museum of London and Norwich Castle Museum), the North Sea material (Mol and Postprivate collections), the Hungarian locality of Györújfalu (=Györ) (Mol private collection) and the major German collections: Mosbach and Upper Rhine Valley (Natural History Museum of Mainz), Mauer (Staatliches Museum für Naturkunde, Karlsruhe), Bilshausen (University of Göttingen), Untermassfeld, Voigtstedt, Süssenborn, Ehringsdorf and Taubach (Institute for Quaternary Paleontology, Weimar) (Fig. 1).

For material not personally analysed, we accept the original identifications in some cases while in others we propose new allocations based on the descriptions, pictures and measurements reported by the authors. All localities whose moose records have been confirmed in the present analysis are listed in the appendix (Table A1) with the geographical indications and the numbering that will be the key to the location maps (Figs. 2-5) and to the dispersion graphs (Figs. 7 and 8). The same numbering is given in superscript for the localities cited in the text, in order to facilitate its identification to the reader. We choose to exclude from the main text all those remains which identification cannot be verified, and to put them in the appendix (Table A2) with the original identification and the references, so that they are available for further research.

Size differences between the Siberian and the coeval European remains (Sher, 1974) and limited data from the literature make it difficult to carry out size comparisons and thus to verify the specific identifications of the Siberian remains. For this reason, in the biochronological section (Section 6), some of the Siberian remains will be compared with the European ones without proposing a specific allocation. Following a re-examination of the entire Siberian record, a systematic interpretation will be suggested which is discussed in Section 7.

New paleomagnetic, radiometric, biostratigraphic and biochronological data allow a biochronological revision of the Eurasian mammal assemblages of Villafranchian and Galerian age, begun by Gliozzi et al. (1997), Marchetti (1998) and Sardella et al. (1998), and now in progress using Marchetti's large data base. The numerous records of Eurasian fossil Alceini are reanalysed here in an attempt, to provide a more refined picture of their chronological and geographical distribution.

One obstacle to chronologically relating moose sites is the difficulty of interpreting data from the literature due to the non-univocal definition of the geochronological and biochronological units and because of the regional meaning of some of them. This problem is obviously present in all the works preceding the formalisation of the boundaries between units; for example, the Plio/ Pleistocene boundary (Kolfschoten and Gibbard, 1998). In this work we make use of the bio- and geochronological scheme proposed by Gliozzi et al. (1997), with some modifications and of a rough correlation between this scheme and the ones from other Eurasian regions, represented in Fig. 1.

\section{Biochronology: Type localities}

A basic problem in defining the biochronological distribution of Cervalces is the dubious dating of the localities of the holotype of the three species. Thus the stratigraphical status of the type localities is discussed here in detail. 


\begin{tabular}{|c|c|c|c|c|c|c|c|}
\hline $\begin{array}{c}\text { Western Europe } \\
- \\
\text { Geochronological } \\
\text { subdivisions } \\
\text { Gliozzi et al., 1997 }\end{array}$ & \begin{tabular}{c|} 
Northern Europe \\
- \\
Geochronological \\
subdivisions \\
(Gibbard et al., 1991) \\
\end{tabular} & $\begin{array}{c}\text { Eastern Europe } \\
- \\
\begin{array}{c}\text { Geochronological subdivisions } \\
\text { (Vangengeim and Pevzner, } \\
\text { 1991; Foronova, 2001b) }\end{array} \\
\end{array}$ & \begin{tabular}{|c|} 
Italy \\
- \\
Large Mammal \\
Ages \\
(Gliozzi et al., 1997) \\
\end{tabular} & $\begin{array}{c}\begin{array}{c}\text { Western and Central } \\
\text { Europe } \\
- \\
\text { Small Mammal Ages } \\
\text { (Fejfar et al., 1998) }\end{array} \\
\end{array}$ & \begin{tabular}{|c|} 
Eastern Europe \\
- \\
Faunal Complexes \\
(Vangengeim and Pevzner, \\
1991; Foronova, 2001b) \\
\end{tabular} & \begin{tabular}{|c|} 
Western Siberia \\
- \\
Faunal Complexes \\
(Vangengeim, 1977; \\
Foronova, 2001b) \\
\end{tabular} & 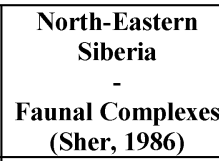 \\
\hline \multirow{2}{*}{$\begin{array}{c}\text { Late } \\
\text { Pleistocene }\end{array}$} & \multirow{2}{*}{$\begin{array}{l}\text { Late } \\
\text { Pleistocene }\end{array}$} & \multirow{2}{*}{$\begin{array}{c}\text { Upper } \\
\text { Neopleistocene }\end{array}$} & \multirow{2}{*}{$\begin{array}{c}\text { Late } \\
\text { Aurelian }\end{array}$} & \multirow{4}{*}{$\begin{array}{l}\text { Late } \\
\text { Toringian }\end{array}$} & Late Mammoth & Late Mammoth & \multirow{2}{*}{$\begin{array}{c}\text { Late } \\
\text { Pleistocene }\end{array}$} \\
\hline & & & & & Shkurlatovian & 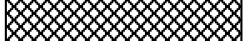 & \\
\hline \multirow{5}{*}{$\begin{array}{l}\text { Middle } \\
\text { Pleistocene }\end{array}$} & \multirow{4}{*}{$\begin{array}{l}\text { late Middle } \\
\text { Pleistocene }\end{array}$} & \multirow{4}{*}{$\begin{array}{c}\text { Middle } \\
\text { Neopleistocene }\end{array}$} & Middle Aurelian & & Early Mammoth & Early Mammoth & late Middle \\
\hline & & & $\mathrm{Ea}$ & & Khazarian & Elements of Khazar & Pleistocene \\
\hline & & & Aurelian & \multirow{2}{*}{$\begin{array}{l}\text { Early } \\
\text { Toringian }\end{array}$} & Singilian & 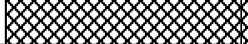 & \\
\hline & & & Late Galerian & & \multirow{2}{*}{ Tiraspolian } & \multirow{2}{*}{ Viatkinan } & \\
\hline & $\begin{array}{l}\text { Early Middle } \\
\text { Pleistocene }\end{array}$ & $\begin{array}{c}\text { Lower } \\
\text { Neopleistocene }\end{array}$ & $\begin{array}{c}\text { Middle } \\
\text { Galerian }\end{array}$ & Late Biharian & & & $\begin{array}{l}\text { Upper Olyorian } \\
\text { (Akanian) }\end{array}$ \\
\hline \multirow{3}{*}{$\begin{array}{c}\text { Early } \\
\text { Pleistocene }\end{array}$} & \multirow{5}{*}{$\begin{array}{c}\text { Early } \\
\text { Pleistocene }\end{array}$} & Upper Eopleistocene & Early Galerian & \multirow{3}{*}{$\begin{array}{c}\text { Early } \\
\text { Biharian }\end{array}$} & \multirow[t]{2}{*}{ Tamanian } & \multirow[t]{2}{*}{ Razdolean } & \multirow{2}{*}{$\begin{array}{l}\text { Lower Olyorian } \\
\text { (Chukochyan) }\end{array}$} \\
\hline & & \multirow{2}{*}{$\begin{array}{c}\text { Lower } \\
\text { Eopleistocene }\end{array}$} & \multirow[b]{2}{*}{$\begin{array}{c}\text { Late } \\
\text { Villafranchian }\end{array}$} & & & & \\
\hline & & & & & Psekupsian $=$ Odessian & Kizikhan & \\
\hline \multirow[t]{2}{*}{ Late Pliocene } & & \multirow{3}{*}{$\begin{array}{l}\text { Upper } \\
\text { Pliocene }\end{array}$} & \multirow{2}{*}{$\begin{array}{c}\text { Middle } \\
\text { Villafranchian }\end{array}$} & $\begin{array}{c}\text { Late } \\
\text { Villanyian }\end{array}$ & \multirow{2}{*}{ Khaprovian } & \multirow[t]{2}{*}{ Podpusk-Lebyazhean } & \\
\hline & & & & \multirow{2}{*}{$\begin{array}{c}\text { Early } \\
\text { Villanyian }\end{array}$} & & & Kutuyakhan \\
\hline Middle Pliocene & Late Pliocene & & Early Villafranchian & & Skorchelskian & Betekean & \\
\hline
\end{tabular}

Fig. 1. Rough correlation among the geochronological subdivisions of Pliocene and Pleistocene, respectively, in Western, Northern and Eastern Europe, the Large Mammal and Small Mammal Ages from Western and Central Europe, and the Eastern European, Western Siberian and North-Eastern Siberian Faunal Complexes. 


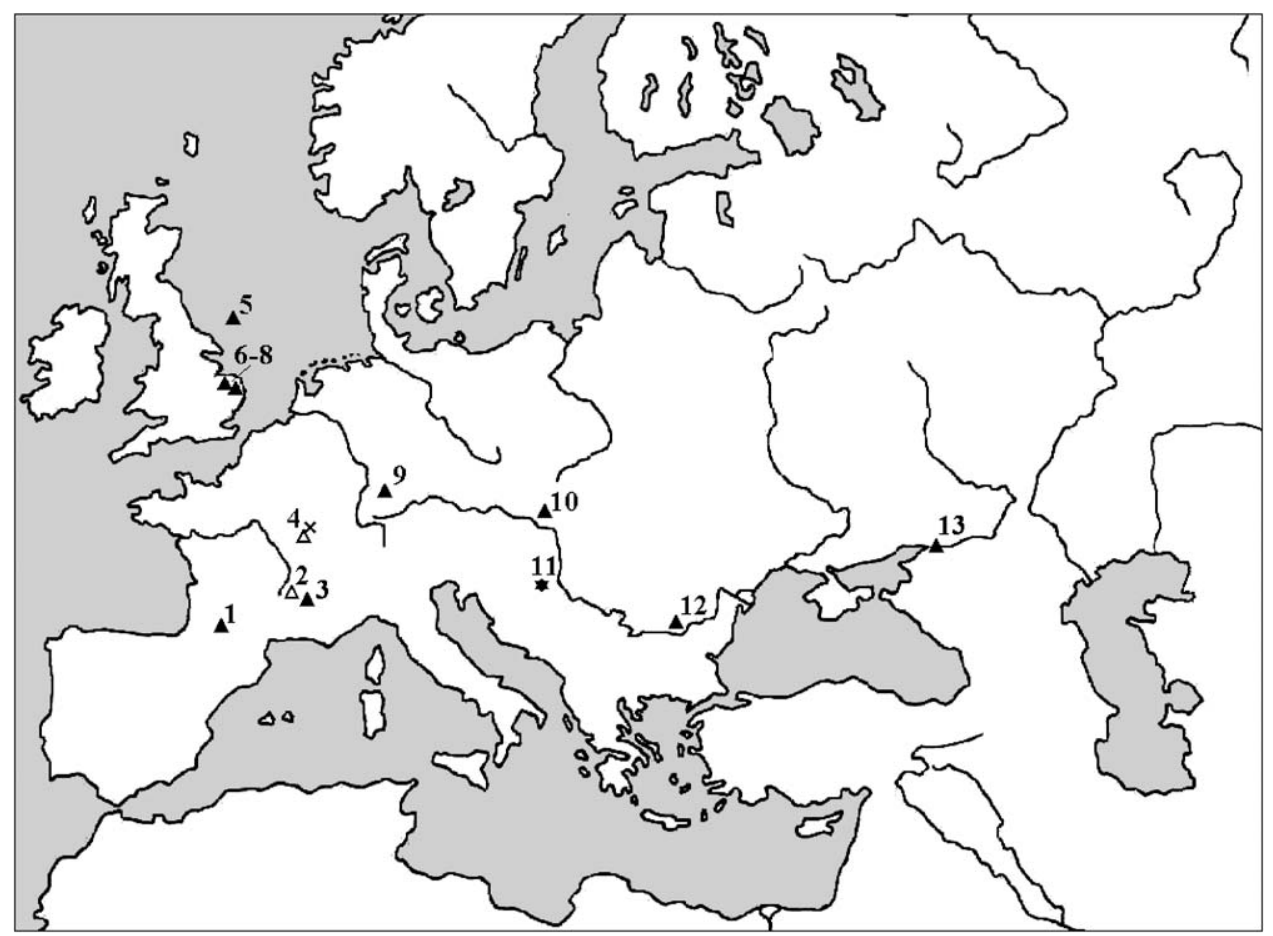

Fig. 2. Map of the Pliocene moose records in Europe. $(\mathbf{\Delta})$ Cervalces gallicus; $(\triangle)$ Cervalces sp.; $(\mathbf{*})$ Alceini indet; $(\mathbf{x})$ Cervidae indet. The number of each locality refers to Table 1 (the same numbering is given in superscript of the localities when cited in the text).

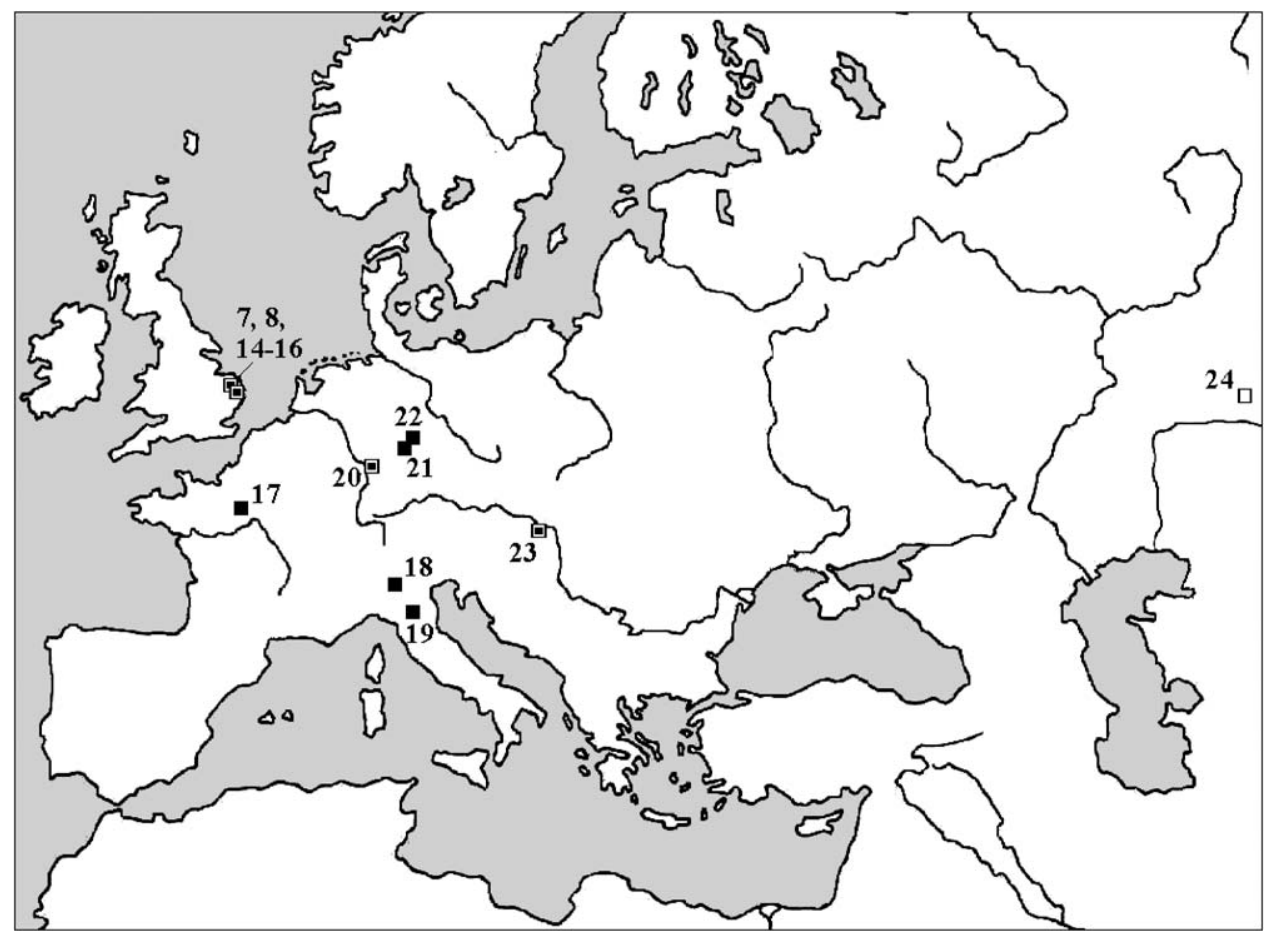

Fig. 3. Map of the early Early Pleistocene moose records in Europe. ( $\mathbf{\square}$ ) Cervalces carnutorum; (回) Cervalces cf. carnutorum; ( $\square$ ) C. carnutorum? The number of each locality refers to Table 1 (the same numbering is given in superscript of the localities when cited in the text).

\subsection{Senèze $e^{(3)}$}

The $C$. gallicus holotype comes from the sedimentary sequence of Senèze, which fills a volcanic structure.
Volcanic activity began with a basaltic flow, which gave a negative p.p. (p.p. $=$ paleomagnetic polarity) and, through $\mathrm{K} / \mathrm{Ar}$ dating, an age of $2.3,2.25$ and 2.49-2.48 Ma, according to the different authors (Boeuf 


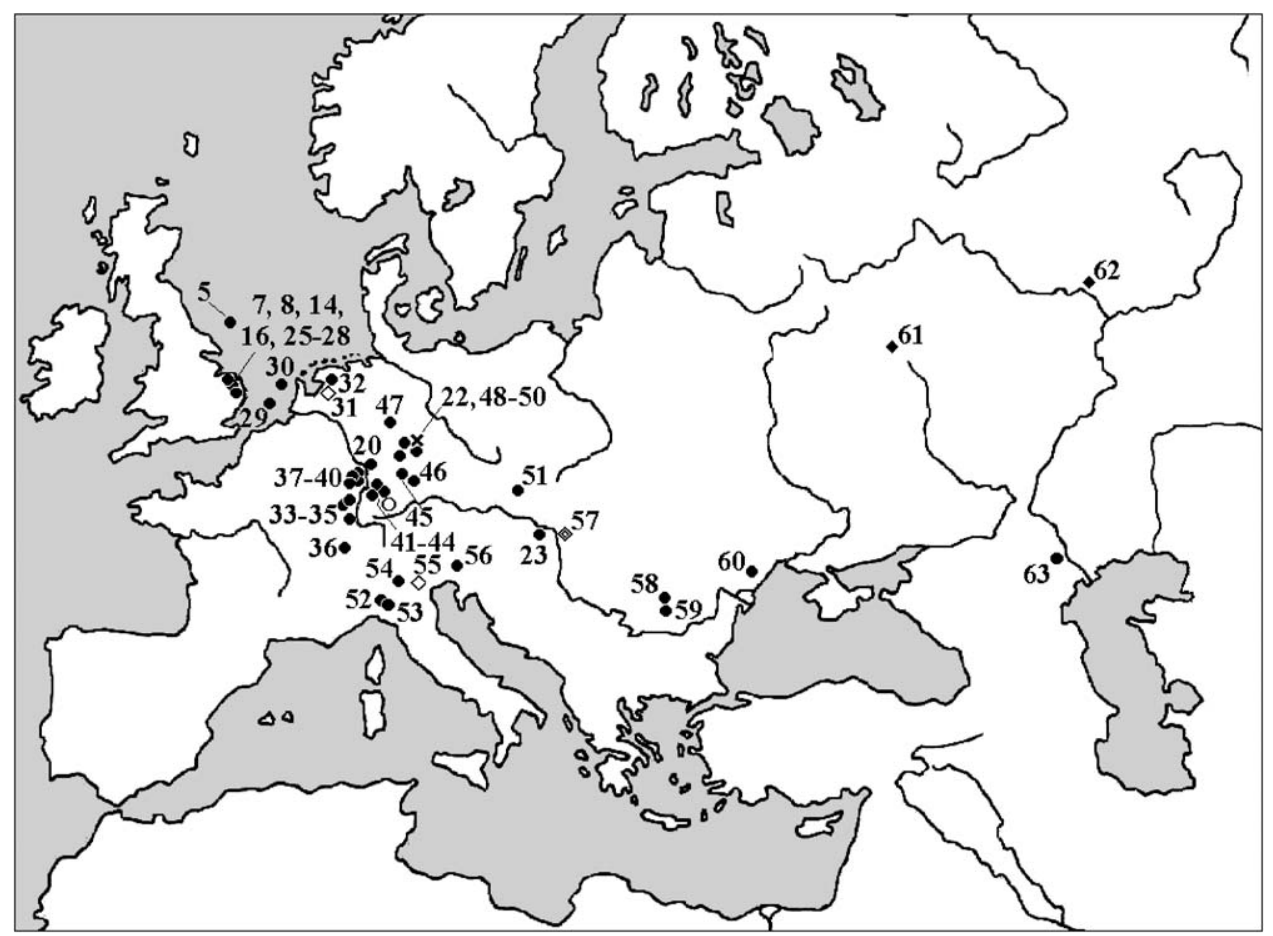

Fig. 4. Map of the late Early Pleistocene to Late Pleistocene moose records in Europe. $(\bullet)$ Cervalces latifrons; $(\bigcirc)$ Cervalces sp.; $(\diamond)$ Alces brevirostris; $(\diamond)$ Alces cf. alces; $(\diamond)$ Alces sp.; $(\mathbf{x})$ Cervidae indet.; $(\diamond)$ Alces alces of probable Late Pleistocene age. The number of each locality refers to Table 1 (the same numbering is given in superscript of the localities when cited in the text).

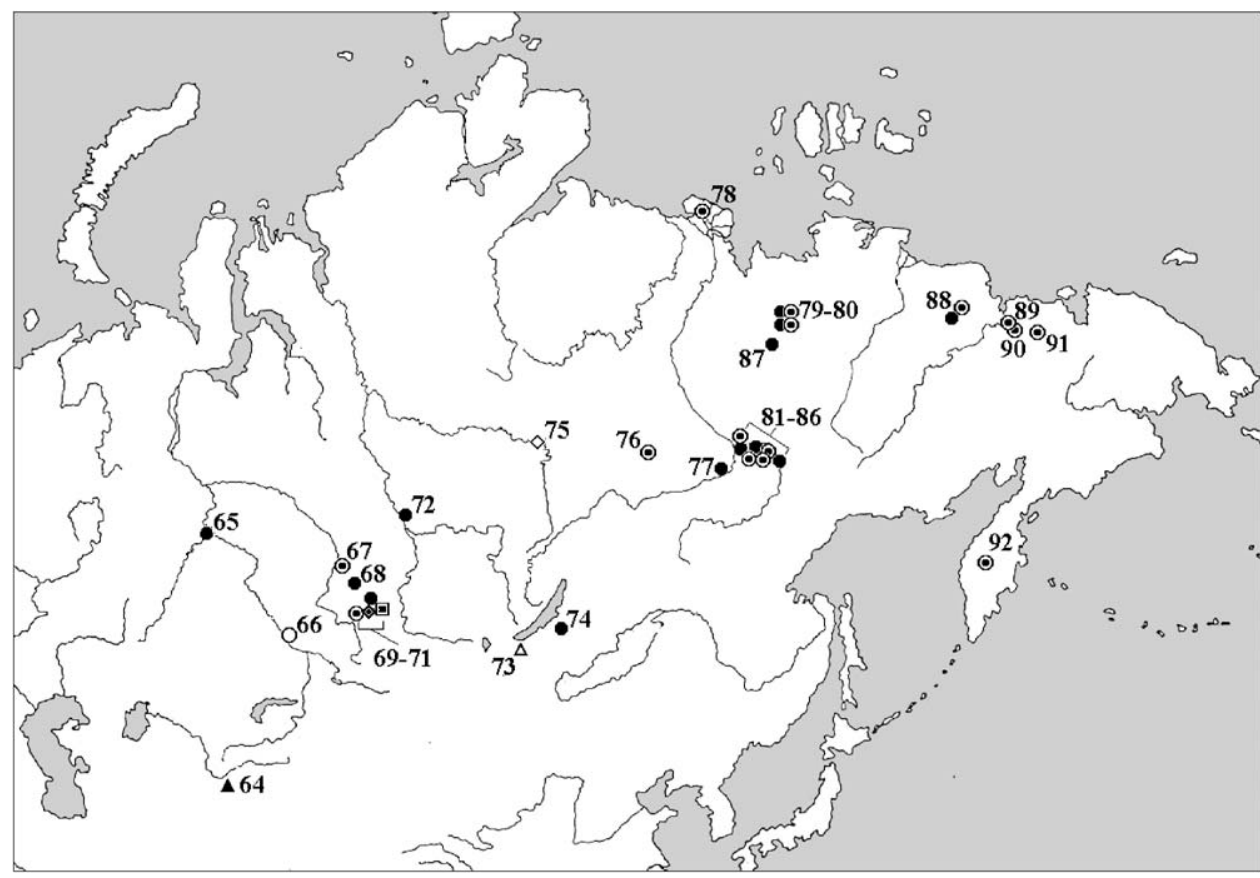

Fig. 5. Map of the Cervalces records in Asia. $(\triangle)$ Cervalces sp. of Pliocene age; $(\mathbf{\Delta})$ C. gallicus; $(\square)$ Cervalces cf. carnutorum; $(\bullet)$ C. latifrons; $(\odot)$ C. latifrons postremus; $(\bigcirc)$ C. latifrons?; $(\diamond)$ Alces cf. alces; $(\diamond)$ Alces sp. The number of each locality refers to Table 1 (the same numbering is given in superscript of the localities when cited in the text).

et al., 1992). Later, an explosion formed a caldera and produced volcanic breccias and scoriae covering the flow. The volcanic lake was filled by maar deposits, ca
$175 \mathrm{~m}$ thick. Several boreholes were constructed which permitted a study of the sporo-pollenic flora, the sedimentology, the diatoms and the paleomagnetism. 
The overall sediments, covered by slope deposits in the area that supplied the fauna, gave an inverse p.p., except for a level between -17 and $-22 \mathrm{~m}$, with positive p.p., assigned to the Réunion or Olduvai Subchrons, according to various authors (Boeuf et al., 1992). The entire sedimentary sequence covers $0.2-0.3 \mathrm{Ma}$ as shown by studies on diatoms by Ehrlich in 1968 (Ehrlich, 1968). Prevot and Dalrymple (1970) assert that the positive p.p., which is too short to represent the Olduvai Subchron (with a length of ca $180 \mathrm{ka}$ ), is easier to interpret as the Réunion Subchron (with a length of ca $10 \mathrm{ka}$ ) and consequently datable at 2.0-2.1 Ma. A tephra layer interbedded in the sediments with the normal p.p. was recently dated at $2.10 \pm 0.01 \mathrm{Ma}$ by the ${ }^{40} \mathrm{Ar} /{ }^{39} \mathrm{Ar}$ method (Roger et al., 2000). Using this chronological marker, it was confirmed that the normal p.p. episode corresponds to the Réunion Subchron. This chronological calibration was also employed to demonstrate that the Villafranchian mammal fauna found in the Senèze maar is younger than the Réunion Subchron. Furthermore, climatic events recorded in the Senèze sequence could thus be related to the marine $\delta^{18} \mathrm{O}$ records. This suggested that the Senèze pollen sequence $(5-120 \mathrm{~m}$ depth) ranges from isotopic stage 85 to 76 (Roger et al., 2000).

The fauna (Schaub, 1943; Heintz et al., 1974) was collected from two fossiliferous levels. The older one, at approximately $10 \mathrm{~m}$ above the positive p.p. and about $10 \mathrm{~m}$ below the surface, had whole skeletons, while the younger one in the slope deposits had fragmentary remains (Bout, 1972, fide Azzaroli et al., 1988). Azzaroli et al. (1988) thus recognise a Middle and a Late Villafranchian fauna. The former should include the majority of the specimens, among them Eucladoceros senezensis $(=E$. tegulensis), Cervus philisi (=Rusa rhenana), and Croizetoceros ramosus. The latter should consist of Canis arnensis (C. senezensis in Martin, 1973), Equus bressanus (E. major in Forsten, 1998; Alberdi et al., 1998), and the small Equus stehlini (Equus stenonis senezensis in Boeuf, 1997, Equus senezensis senezensis in Alberdi et al., 1998), Megalovis latifrons. Azzaroli et al. (1988) place C. gallicus in the latter fauna. In contrast Lister (1993a) assumes that the level of preservation of C. gallicus indicates an origin from the maar deposits, which are the source of articulated skeletons, and not from the overhanging slope deposits, which yielded only fragmentary remains. Although the fauna is said to come from two levels, it seems to represent a homogeneous Middle Villafranchian assemblage. Equus major, small Equus, Megalovis and Canis are, indeed, usually found in Middle Villafranchian faunas, such as Erpfingen 2, in Germany (Sotnikova, 1989; Forsten, 1998), Varshets and Slivnitsa, in Bulgaria (Spassov and Crégut-Bonnoure, 1999), Cornillet, in France (Biquand et al., 1990), Costa San Giacomo, in Italy (Palombo et al., 2000-2002) Kuruksay, in Tadzhikstan (Sotnikova et al., 1997; Forsten and Sharapov, 2000), Liventsovka m.1., in Russia (Forsten, 1998; Sotnikova et al., 2002). Moreover, Boeuf (1997) notes that the clayey recurrence in the slope deposits is not sufficient evidence for chronological gap of some importance between the two fossiliferous levels. On the other hand, it is possible that, during the erosion of the slope, the slope sediments were mixed with lacustrine deposits of the maar banks.

Hippopotamus cf. antiquus (Mazza and Rustioni, 1994) and "Ovis" (Schaub, 1943) were originally assigned to the Senèze fauna. As a matter of fact, the former comes from a different locality, namely Domeyrat (Mazza and Rustioni, 1994). The latter exhibits a different state of preservation from all the other remains from Senèze (Crégut-Bonnoure, 1992). The data described above allow us to correlate the fauna including C. gallicus with high probability to OIS 78 and/or 76 .

\subsection{Saint Prest ${ }^{(17)}$}

The C. carnutorum type from St. Prest consists of two upper molars, which are part of material, actually belonging to different deer, used by Laugel (1862) to describe the species Megaceros carnutorum. Heintz and Poplin (1981) maintain that the type specimen of "carnutorum" should be the only illustrated by Laugel, i.e. the moose $M^{2}$, which they chose as lectotype of $A$. carnutorum, and suggest that this species is intermediate in age and size between $C$. gallicus and C. latifrons. In contrast Pfeiffer $(1999 a, 2002)$ suggests that "carnutorum" should be considered as nomen dubium and points that the M. carnutorum described by Laugel represents the early giant deer Megaloceros verticornis. Several other remains form St. Prest can be assigned to $C$. carnutorum, including a left frontal with base of the antler (Heintz and Poplin, 1981), a metatarsal (Breda, 2001b; Guérin et al., 2003), already described by Laugel (1862) and then illustrated by Gervais (1867-69), a first phalanx, a distal tibia and five astragals (Guérin et al., 2003). The other phalanx assigned to $C$. carnutorum by Guérin et al. (2003) has the proportions of $M$. verticornis, also present at the site.

The Saint-Prest fauna, that yielded the holotype of $C$. carnutorum, was described several times, starting from the middle of the nineteenth century. Identifications of many of the remains by earlier authors are questionable, as some material has been lost. Recently the fauna was revised (Guérin et al., 2003). It is made up of Trogontherium cuvieri boisvilletti, Mammuthus meridionalis depereti (M. meridionalis highly evolved, according to Ferretti, 1997), Stephanorhinus etruscus brachycephalus (S. hundsheimensis sensu Fortelius et al., 1993), Bison cf. schoetensacki, M. verticornis (Eucladoceros giulii, according to Lister, pers. comm.), Cervus cf. elaphus (C. elaphus acoronatus, according to $\mathrm{Di}$ Stefano and Petronio, 1992). Therefore, it is chronologically 
homogeneous and can be related to the Colle Curti FU. The negative polarity (Guérin et al., 2003) confirms the Early Pleistocene age.

\subsection{Happisburg ${ }^{(25)}$-Cromer Forest—bed}

The Cromer Forest-bed Formation (CF-bF), exposed along the Norfolk Coast of England, is famous for its rich fossil vertebrate fauna. Attempts to relate the fossil remains to stratigraphical schemes are very problematic (Lister, 1996). The first complete modern stratigraphical study was carried out by West (1980), who parted the $\mathrm{CF}-\mathrm{bF}$ in a series of chronostratigraphical levels based on palynological evidence. The older levels are assigned to the cold pre-Pastonian stage, followed by the temperate Pastionan stage, the cold Beestonian stage, the Cromerian Interglacial and the cold Anglian stage. A wide gap is recognised in the Beestonian levels, which spans much of the Early Pleistocene.

Gibbard et al. (1991), Zagwijn (1996) and Lister (1998) tried to relate the English series to the Dutch stratigraphical series using faunal, palynological and lithological data. It turns out that the English PrePastonian and Pastonian are correlated with the terminal phases of the Dutch Tiglian complex and, through paleomagnetic data, with the Olduvai Subchron as well as with a subsequent phase of short length, which might be the one inside this Subchron. The levels corresponding to the Dutch Eburonian, Waalian, Menapian and Bavelian Stages are missing. The English Cromerian s.s. from West Runton can be related to a still uncertain phase of the Dutch Cromerian Complex. Finally, the cold Anglian levels correspond to the Elsterian Cold Stage of the continental stratigraphy. The Beestonian layers of the Norfolk Coast show a reduced span and are very discontinuous in the various localities. They are sometimes considered prior to the hiatus (related to the first phases of the Eburonian) and sometimes subsequent to it (related to one of the earliest glacial phases, maybe the A phase, of the Dutch Cromerian complex).

Azzaroli (1953) first hypothesised a wide hiatus in the CF-bF stratigraphical series, recognising two distinct deer faunas including an older one assigned to the early Late Villafranchian, and a younger one related to the Middle Pleistocene. Lister (1993a, 1996, 1998) confirms the existence of the two faunas proposed by Azzaroli, relates them respectively to the pre-Pastonian and Pastonian levels and to the Cromerian levels described by West (1980), and discusses the problem of attribution of many of the remains to their original horizon. The difficulties are due to insufficient information on the discovery of the remains, at times limited to the name of the nearest coastal village, as well as to the problem of relating the stratigraphical descriptions by the early authors to the present situation, as the cliff underwent major changes since the time the remains were found.

Regarding the $C$. latifrons holotype from Happisburg, Lister (1996) shows that this locality was known for the numerous elephant remains, dredged from the offshore "Oyster Beds", representing almost exclusively the older fauna. On the other hand the beach and the cliff deposits yielded several cervid antlers and numerous elephant teeth belonging to the younger fauna. Newton (1882) maintains that the antler described by Johnson as $C$. latifrons holotype "was obtained from part of the Forest Bed Series exposed at lower water on the beach at Happisburgh". According to the stratigraphical studies by West (1980), at Happisburg only pre-Pastonian and Pastonian sediments are exposed, overlain by till (Lister, 1996). This is a contradiction, since several other mammal remains found here (Ursus deningeri, Mammuthus trogontherii, Bison schoetensacki, M. verticornis, Cervus elaphus, etc.) are typical of the early Middle Pleistocene age, as is C. latifrons from other Western European sites. Lister (1993a, 1996) hypothesizes that early Middle Pleistocene deposits were exposed beneath the till when the fossils were being collected. From here the tidal stream could have carried the antler to the location where it was found. Lister (1996) points out also that the specimen is unlikely to have travelled far, because of its completeness.

The CF-bF localities containing C. latifrons were usually correlated with the Cromerian stratotype of the West Runton Upper FreshWater Bed (WRFB) and to an uncertain phase of the Dutch Cromerian complex (Gibbard et al., 1991) but, on the base of the non-marine Mollusca and of mammal assemblages, are now believed to represent four different temperate stages within the early Middle Pleistocene (Meijer and Preece, 1996; Preece, 2001; Stuart, pers. comm.).

\section{Biochronology: Western, Central and Balkanic Europe}

The oldest moose, identified as Alces sp., should be the one from Csarnóta 2 u.l. $^{(11)}$ (u.l. = upper level) (Schaub, 1933; Kretzoi, 1962; Kahlke, 1990). The semilunar bone described by Schaub can only be assigned to the Alceini tribe. The associated mammal fauna (Kretzoi, 1962; Hír, 1996; Crégut-Bonnoure and Spassov, 2002) is related to the Early Villanyian (Dolomys milleri, Cricetinus janossyi, etc.) and the Early Villafranchian (Hemitragus orientalis, Procamptoceras cf. brivatense, etc.).

The Alceini records are numerous and reliable in this geographical area from the Late Pliocene onward.

Depéret (in: Delafond and Depéret, 1893) established his Cervus douvillei on the basis of two very incomplete antler fragments collected around Chagny ${ }^{(4)}$ and Perrigny ${ }^{(4)}$, from the lower yellow sandy sediments of the 
Bresse basin. As suggested by Heintz and Poplin (1981), the antler from Perrigy remains unidentified. Freudenberg (1914) referred to the specimen from Chagny, which is now lost, as A. latifrons (C. latifrons being the only Cervalces species already described at that time). As suggested by Heintz and Poplin (1981), on the basis of the drawings and description by Depéret, this antler cannot be identified at specific level and we refer to it as Cervalces sp. In fact the beam is certainly much longer than in living moose but it is broken prior to the widening in the palmation and so its length remains unknown. The fauna collected in the lower sands around the area of Chagny (Mayet and Roman, 1923; Friant, 1951; Bourdier, 1961; Forsten, 1998) is mixed (Samson, 1975), since it is attributable to both the Early and the Middle Villafranchian (Tapirus arvernensis and Mammut borsoni together with E. major and Mammuthus similar to M. gromovi).

The karst deposits of Erpfingen $2^{(9)}$ (=Erpfingen Höhle) produced a $P_{2}$ and a $M_{3}$ assigned to Libralces gallicus by Lehmann (1953, 1957). Heintz and Poplin (1981) confirm this identification through the size of the $M_{3}$, which is a little smaller than the holotype from Senèze. The moose is associated with a fauna (Tobien, 1974) similar to the one from Senèze, and is, therefore, assigned to the Senèze FU (Marchetti, 1998).

From Strekov-Nová Vieska ${ }^{(10)}$ ?Cervalces $\mathrm{sp}$. is recorded along with a mixed fauna (Harčár and Schmidt, 1965; Schmidt and Halouzk, 1970; Holec, 1996) of Early and Middle Villafranchian type. The dimensions of the teeth and of one fragmentary antler permit the assignment of this moose to $C$. gallicus.

C. gallicus from Prundu ${ }^{(12)}$ (Apostol, 1972; Rădulescu et al., 1993), only roughly datable to the Middle or Late Villafranchian, consists of an antler beam, whose measurements confirm the original identification.

Clot et al. (1976) record Libralces? gallicus? from Montoussé $5^{(1)}$. Heintz and Poplin (1981) identify at least two teeth well attributable to $C$. gallicus based on size and morphology. The mammal assemblage is ascribed to the Olivola FU (Marchetti, 1998).

Moose remains, from CF-bF of Dogger Bank ${ }^{(5)}$, East Runton $^{(6)}$, Sidestrand ${ }^{(7)}$ (Azzaroli, 1953) and Overstrand $^{(8)}$ (Lister, 1996) can be assigned to C. gallicus. They were collected in or are believed to originate from the exposed Pre-Pastonian and Pastonian levels of the $\mathrm{CF}-\mathrm{bF}$, as other mammal remains, such as Megaloceros obscurus, Eucladoceros and typical M. meridionalis (Azzaroli, 1953; Stuart, 1974, 1982, 1996; Lister, 1996, 1998; Forsten, 1998). This fauna is here considered to be linked to the Olivola FU.

The oldest remain designated as C. carnutorum is represented by a fragmentary right metatarsus, not less than $420 \mathrm{~mm}$ in length, from Blassac-la-Girondie ${ }^{(2)}$ (Boeuf et al., 1992). The size, intermediate between $C$. gallicus and C. latifrons, induced Kahlke (1995) to assign an age of 1.2-1.3 Ma. Geraads (1990) and Boeuf et al. (1992) ascribe to Blassac an intermediate age between Senèze and Peyrolles, on the basis of the evolutionary level of the deer specimens. Nevertheless, the age of the fauna, due to the presence of Pliocrocuta perrieri, which persists in Western Europe till the end of Middle Villafranchian, is older than the English localities with $C$. gallicus and can be ascribed to the Senèze FU or, at most, to the Olivola FU. The basalt, with positive p.p., overhanging the fossiliferous levels of Blassac, produced contradictory $\mathrm{K} / \mathrm{Ar}$ ages, but new analysis suggests an age of 2.0-1.85 Ma. Thus, the basalt should be correlated with the Olduvai Subchron (Boeuf et al., 1992; Boeuf, 1997). If we accept this age and the reconstructed length of the metatarsus, this specimen confirms the wide size range of the Cervalces species which does not allow, alone, a reliable species assignment. We believe that this remain can be only determinable as Cervalces sp.

A shed antler beam from Il Crostolo ${ }^{(19)}$ was identified as L. gallicus by Ambrosetti and Cremaschi (1976). The beam, of about $30 \mathrm{~mm}$ in length, is much shorter than the approximately $60 \mathrm{~mm}$ long beam of the C. gallicus holotype from Senèze which, however, has the same diameter. For this reason, Breda (2002) attributed this specimen to C. carnutorum. The fauna from Il Crostolo, collected from different beds (Ambrosetti and Cremaschi, 1976; Masini et al., 1990; Ferretti, 1997), is ascribable to the Tasso FU, because of the presence of M. meridionalis, Canis cf. etruscus, S. etruscus and Hippopotamus cf. antiquus.

C. carnutorum has been recently described by Breda (2002) at Leffe $^{(18)}$, from the first (upper) brown-coal bank of the Leffe Formation. The specimen consists of the right frontal bone of a male with the pedicle compressed in a dorso-ventral plane as typical of the genus Cervalces in comparison to Alces (Breda, 2002). The size and proportions of this frontal suggests that the specimen belongs to the species $C$. carnutorum. The associated fauna (Breda and Marchetti, 2003) is Late Villafranchian in age. The Leffe Formation is located above layers paleomagnetically correlated with the Olduvai Subchron and beneath others related to the Jaramillo Subchron (Ravazzi and Moscariello, 1998).

Moreover, C. carnutorum comes from the German localities of Untermassfeld ${ }^{(21)}$, Mosbach $1^{(20)}$ and Voigtstedt ${ }^{(22)}$, as confirmed by us.

Untermassfeld is dated to the beginning of the Jaramillo Subchron according to paleomagnetic studies (Kahlke, 2000). Some species recorded here are of Villafranchian type [Pseudodama nestii vallonnetensis (=Axis eurygonos), E. giulii, Acinonyx pardinensis pleistocenicus, Megantereon cultridens adroveri $(=M$. whitei)], others are characteristic of the Galerian (Canis mosbachensis, Sus scrofa priscus) and yet others are chronologically intermediate $[S$. etruscus 
(morphologically intermediate between the Late Villafranchian one from Upper Valdarno and the Middle Pleistocene one from Voigtstedt and Süssenborn), Capreolus cusanoides (more primitive than C. suessenbornensis), Bison menneri and Ursus rodei (Kahlke, 2001a)]. This is a typical mammal assemblage of the Colle Curti FU.

The Mosbach deposits consist of two main lithological levels, which can be distinguished faunistically, too (Kahlke, 1960; Keller, 2004). The lowest, Mosbach 1 or "Grobes Mosbach", consists of coarse deposits showing cold or cool climatic conditions (Nilsson, 1983) and is placed beneath a sample with positive p.p. assigned to the Jaramillo Subchron (Brüning, 1978; Koenigswald and Tobien, 1987; Koenigswald and Heinrich, 1999). According to Reichenau (1900), some skulls of $A$. latifrons with particularly long beams originated from this level. Kahlke $(1960,1961)$ notes the resemblance of these remains to the L. gallicus from Senèze and Heintz and Poplin (1981) relate them to A. carnutorum. According to the measurements, only few remains from Mosbach can be attributed to $C$. carnutorum with confidence. Others are consistent with both $C$. carnutorum and C. latifrons. Mosbach 1, through paleomagnetic and faunal data (C. cf. carnutorum, M. meridionalistrogontherii, Capreolus sp., M. verticornis, etc.) (Brüning, 1978; Koenigswald and Heinrich, 1999), should be roughly coeval to Untermassfeld.

A rich mammal fauna was found at Voigtstedt (Kahlke, 1965). The majority of moose remains, attributed to $A$. latifrons, and nearly the entire fauna, were collected from the middle level (Kahlke, 1958, 1965), which is characterised by coarse sands at the base of the "Lehmschichten" (clays and organic silts). The "Lehmschichten" contained forest type pollens and was chosen to represent the Voigtstedtian warm phase. It lies above the "Unteren Kiesen" (lower gravel sands), representing the Elmian cold phase and with a paleomagnetic age around the Matuyama/Brunhes boundary (Wiegank, 1990), and beneath the "Oberen Kiesen" (upper gravel sands), loess and tills correlated with the Elsterian Cold Stage. The moose jaw Voi 1312 and the moose frontal bone Voi 1241, due to the different type of fossilisation (Breda, 2001b), appear to originate from different levels in comparison with the one bearing the main fauna. Kahlke (1958) suggests that the jaw Voi 1312 belongs to a lower level, because of its moderate size and names it ?Libralces gallicus?. Heintz and Poplin (1981) and Kahlke (1995), naming the same jaw as A. carnutorum, confirm the hypothesis of its provenance from an older level.

Another specimen assigned by Kahlke (1995) to $A$. carnutorum because of its size is the jaw from Mundesley ${ }^{(16)}$ (Savin, 168). The proposal made by Kahlke should imply the existence, in the CF-bF, of intermediate levels between those of pre-Pastonian to Pastonian age and those of Cromerian age. The
Bestonian Stage represents a long interval, including many climatic cycles, covering almost the entire English Early Pleistocene following the Pastonian stage (Lister, 1998). At present, certain Beestonian beds occur at West Runton (Lister, 1996). West (1980) describes a set of deposits that stand in a higher stratigraphic position, intermediate between the Pastonian and the Cromerian ones, and are lithologically similar to the Pastonian ones. These deposits are coarse ferruginous sands joined with clayey conglomerates, cropping out along the seaboard between Cromer and Overstrand, at Mundesley and at Bacton (Lister, 1998), which point to a likely regression (i.e. cold phase). Lister states that in the majority of the localities with Pastonian levels from which large mammals were collected, Bestonian levels which probably produced mammal remains are present too. Strong lithological resemblance suggests that some of the fossiliferous beds described by earlier authors are of Beestonian age. These data confirm a possible Beestonian age for the Mundesley jaw which, therefore, should belong to C. carnutorum, as stated by Kahlke (1995). In any case, the same systematic position could be invoked for all the other remains of the same size found in the CF-bF (two jaws from Cromer ${ }^{(14)}$ and Walcott $^{(15)}$ (Azzaroli, 1953) and two more from Sidestrand $^{(7)}$ and Overstrand ${ }^{(8)}$ (Breda, 2001b)). The abovementioned moose remains from Mundesley, Walcott, Cromer, Ovestrand and Sidestrand, are here assigned to C. cf. carnutorum.

A moose, named $A$. latifrons, is recorded from Győrújfalu $^{(23)}$ (Jánossy and Krolopp, 1994). The dimensions of its teeth, skulls, antlers and postcranial remains range between those from Senèze and the ones from the German localities which produced $C$. latifrons. Two distinct dimensional groups are present, one intermediate between $C$. gallicus and $C$. carnutorum and one similar to $C$. latifrons. The associated mammal assemblage is mixed, containing, for example, among proboscideans, $M$. meridionalis advanced form, $M$. trogontherii and Elephas antiquus (Jánossy and Krolopp, 1994; Mol, pers. comm.), and suggests a Late Villafranchian and a Galerian age. The moose remains are here assigned to $C$. cf. carnutorum and $C$. latifrons.

C. latifrons from the lacustrine basin of Ranica ${ }^{(54)}$ (Azzaroli, 1979) is related to the Jaramillo Subchron on the basis of paleomagnetic and palynological data (Breda et al., 2004; Ravazzi et al., 2004). This is the oldest known C. latifrons from Western Europe to date. It consists of an adult male braincase and a shed antler beam probably belonging to a young individual. The specific assignment by Azzaroli (1979) is confirmed by Breda (2002). In fact, the skull is massive, one of the largest of the species, and the antler beam is very short, even belonging to a young animal because of its small diameter, so the rate length/circumference is close to the lower limit, even for $C$. latifrons. 
Praealces aff. gallicus from Vič Terrace ${ }^{(56)}$ (Rakovec, 1954, 1956, 1975), consisting of a left mandible with $P_{2}-M_{1}$ and a fragmentary right mandible, belongs to C. latifrons, as evident from its large size. No other fossil mammal remains were found there. This allows a biochronological allocation approximately to the Middle Pleistocene.

At Het $\mathrm{Gat}^{(30)}$ a fragment of a skull with a partial antler and some postcranial elements of $C$. latifrons were found along with a mammal fauna correlated with the Leerdam Interglacial (Post et al., 2001). The mammal assemblage can be assigned to the Colle Curti FU, due to the presence of $B$. menneri, Megaloceros savini and Eucladoceros, among others. The dimensions of the antler confirm the species attribution made by Post et al.

The Würzburg-Schalksberg ${ }^{(45)}$ fauna produced $C$. latifrons (Mäuser, 1990) along with an Early Galerian fauna (Kahlke, 1997; Koenigswald and Heinrich, 1999). Mäuser states that the moose teeth from Würzburg are comparable to those from Mosbach 1 because of the presence of some archaic features. However, these features are not believed to be valid by Pfeiffer (1999a) and Breda (2001a,b). The Würzburg-Schalksberg assemblage can be assigned to the Slivia FU, because of the appearance of Praeovibos cf. priscus and $C$. suessenbornensis.

C. latifrons was found in many early Middle Pleistocene age German localities corresponding to the Slivia and Isernia FU based on the presence of $M$. verticornis, M. trogontherii, Equus ferus mosbachensis, Equus suessenbornensis, C. elaphus acoronatus and Stephanorhinus hundsheimensis. Among them are the classic Voigtstedt m.1. ${ }^{(22)}$, Süssenborn m.1. ${ }^{(49)}$, Mosbach $2^{(20)}$ and Mauer $^{(43)}$ localities, rich in cranial and postcranial moose remains examined by Breda.

Kahlke $(1958,1965)$ studied the moose remains from Voigtstedt. Koenigswald and Heinrich (1999), on the basis of paleomagnetic and faunal data, place the middle level of Voigtstedt into the basal Middle Pleistocene, which corresponds, for these authors, to the Matuyama/ Brunhes boundary. The faunal interglacial character, the taxa here present and the paleomagnetism permit the correlation of the fauna to the OIS 19 and to an intermediate phase of the Slivia FU.

The Süssenborn fauna was collected from coarse sandy deposits, which belong to the Ilm River terrace system, covered by till deposits of the Elsterian Cold Stage (Nilsson, 1983). These sandy sediments can be divided into two cold phases alternating with an altered horizon which is evidence for a warm interval (Steinmüller, 1972). In Süssenborn three fossiliferous levels exist (Kahlke, 1961). C. latifrons originates from the middle level (Kahlke, 1956-59, 1969) as the majority of the fauna (Koenigswald and Heinrich, 1999). Koenigswald and Heinrich (1999) consider the Süssenborn fauna from the middle level slightly younger than the one at
Voigtstedt m.1., due to the first appearance of "cold" (artic) taxa, such as Rangifer arcticus stadelmanni and Ovibos moschatus suessenbornensis. This level, due to the presence of M. savini, is older than Mauer and Mosbach 2, where its descendant Arvicola cantianus appears (Koenigswald and Heinrich, 1999), and is correlable to the OIS 16 and to the end of the Slivia FU.

Mosbach 2, or "Graues Mosbach", is the main level at Mosbach which yielded the majority of mammal remains (Koenigswald and Heinrich, 1999), including a rich assemblage of C. latifrons remains (Kahlke 1960). The sediments consist in fluvial grey sands, which are thought to represent a cold phase followed by a warm period (Nilsson, 1983). The sands are underlain by sediments with negative p.p. and overlain by positive ones which are assigned to the Brunhes Chron (Brüning, 1978; Koenigswald and Tobien, 1987). Because of the presence of $A$. cantianus and a fauna of warm character, Mosbach 2 is correlated with the OIS 13 and the Isernia FU.

The Mauer sands were deposited by the Neckar River. Along the old riverbed, several fossiliferous localities of similar age are present, commonly referred to as Mauer (Dieter Schreiber, pers. comm.). The Mauer mammal assemblage (Soergel, 1914; Koenigswald and Heinrich, 1999), exhibiting characteristics of a forest habitat, is assigned to the Cromerian complex and to the Brunhes Chron according to paleomagnetic data (Nilsson, 1983). Because of the presence of $A$. cantianus and of a mammal fauna of warm character, Mauer is considered to be of the same age as Mosbach 2.

C. latifrons remains were collected in several other German localities such as Bilshausen ${ }^{(47)}$ (a partial skull with antlers and some postcranial elements belonging to the same specimen-Schmidt, 1930, 1934), Frankenbach $^{(42)}$ (a mandible with $M_{2}$ and $M_{3}$-Thies, 1926), Aalen Goldshöfe ${ }^{(41)}$ (=Goldshöfer Sande) (both frontals with the almost whole antlers-Hennig, 1952), Jockgrim $^{(37)}$ (two shed antlers-Soergel, 1925; Kuss, 1955-and one astragalus now in the Karlsruhe Museum-Breda, unpublished data), Dorn-Dürkheim $3^{(38)}\left(P_{2}\right.$ and $P_{3}$-Franzen et al., 2000), Mietersheim ${ }^{(35)}$ (a mandible with $M 3$ and partial $M_{2}$-Soergel, 1914) and Kriegsheim ${ }^{(39)}$ (=Worms), (two antlers and one molar-Weiler, 1935; Hennig, 1952). Based on size comparison and/or descriptions, the remains from these localities are considered here to correctly represent $C$. latifrons. In these German localities a mammal assemblage was found, consisting of M. savini or A. cantianus and typical early Middle Pleistocene large mammals, and was considered to predate the Holsteinian Stage (Koenigswald and Heinrich, 1999). This mammal assemblage can as a whole be assigned to the Slivia, Isernia and Fontana Ranuccio FU. Paleomagnetic data corroborate the age inferred using the mammal 
assemblages. Dorn-Dürkheim 3, with negative p.p., barely predates the Matuyama/Brunhes boundary (Franzen et al., 2000), while Bilshausen and Jockgrim, with positive p.p., are of Brunhes age (Wiegank, 1983). Furthermore, Bilshausen is assigned on the basis of pollen assemblage to level $\mathrm{H}$ of Kärlich, which is dated to $396 \pm 20 \mathrm{Ka}$ (Bittmann and Müller, 1996).

Many early Middle Pleistocene mammal assemblages containing $C$. latifrons are reported outside Germany, too. These includes Hangenbieten 1.1. ${ }^{(34)}$ (1.1.=lower level) (a partial jaw with fragmentary $\mathrm{M}_{1}$-Wernert, 1957), Stránská Skála ${ }^{(51)}$ (several lower and upper teeth-Fejfar, 1961; Kahlke, 1972), Feldioara-Cariera 1.1. ${ }^{(58)}$ (two frontals with base of antlers, a jaw with $P_{4}$ $M_{1}$ and a proximal tibia-Rădulescu et al., 1965; Rădulescu and Kovács, 1968), Rotbav-Dealul Țiganilor 1.1. (59) (a distal radius and an axis-Rădulescu et al., 1965), Maasvlakte $1^{(32)}$ (an $M^{3}$ and other undescribed remains-Mol, 1994; Reumer et al., 2000) and Nordzee $2^{(29)}$ (three antler beams-Vos and Mol, 1997; Reumer et al., 2000; Kahlke, 2001b; Kolfschoten, 2001). The existing descriptions and measurements allow confirmation of the species assignment.

In the English CF-bF, in addition to the type locality Happisburgh, C. latifrons is recorded from Dogger Bank $^{(5)}$ (Pfeiffer, 1999a), Sidestrand ${ }^{(7)}$, Overstrand ${ }^{(8)}$, Cromer $^{(14)}$, Mundesley ${ }^{(16)}$, Trimingham ${ }^{(26)}$, West Runton $^{(27)}$ (Azzaroli, 1953) and Pakefield ${ }^{(28)}$ (Dawkins, 1887; Gunn, 1891). The mammal assemblage on the whole (M. savini, Mimomys pusillus, Microtus gregaloides, M. meridionalis a.f., M. trogontherii, Palaeoloxodon antiquus, etc.) (Stuart, 1974, 1996; Lister, 1996; Lister and Sher, 2001; Stuart and Lister, 2001; Stuart, pers. comm.) is assigned to the Slivia FU. The presence of some differences among molluscs and mammals assemblages from the different sites (Meijer and Preece, 1996; Preece, 2001; Stuart, pers. comm.) give grounds to assign them to different temperate stages, correlable to OIS 19,17 and 15 .

Vergranne ${ }^{(36)}$, that yielded several teeth and postcranial elements of a small $C$. latifrons specimen, is dated by Geraads (1983) to the end of the Mindel Glaciation and is believed to be similar to Mauer with respect to age and environment. The species attribution is confirmed here. The presence of Arvicola cf. cantianus together with Sorex (Drepanosorex) savini is typical of mammal faunas related to the Isernia FU.

C. latifrons, assigned to C. l. postremus by some authors, was recorded from Ehringsdorf ${ }^{(48)}$, Taubach ${ }^{(50)}$ and several localities from the Upper Rhine Valley ${ }^{(40)}$, associated with late Middle Pleistocene mammal assemblages which can be correlated with the Italian Aurelian Mammal Age.

At Ehringsdorf, in addition to the teeth and the postcranial elements already mentioned (Section 2.3), a fragmented antler with a typical Cervalces structure is reported, too (Kahlke, 1975a,b). The moose remains found in travertines were at first dated to the Eemian or Eemian-Weichselian based on floral, faunal and stratigraphic considerations (Kahlke, 1975a,b; Nilsson, 1983). However, they are now considered older on the basis of new evolutionary arguments involving the vertebrate remains as well as new dating by ESR and Uranium series. This information led to a reassignment to the Saalian Complex, at OIS 7 (Koenigswald and Heinrich, 1999; Maul, 2000; Schäfer et al., 2004; Schüller, 2004). The mammal fauna is assigned to the Vitinia FU.

Taubach, dated to the Eemian (Koenigswald and Heinrich, 1999), yielded only two moose antler fragments (Kahlke, 1976) neither of which could be identified due to their incompleteness (Breda, 2001b). One consists of a fragment of palmation which may even belong to a different type of deer as it does not have any taxonomical features. The other remain is an antler beam, lacking the burr and broken at the very beginning of the palmation. Kahlke (1976) suggests that the proximal antler end is the part immediately close to the burr, but this assumption is not proven. Thus, the actual beam length cannot be measured and the attribution to the moose, based on the missing basal tines, is questioned by Breda (2001b).

Koenigswald and Menger (1997) assign to A. latifrons postremus two moose shed antler beams from Gross-Rohrheim, in the Upper Rhine Valley. Pfeiffer (1999a, b) reports findings of several antlers, two skulls and a number of postcranial remains belonging to a large A. latifrons from the same valley, at Gross-Rohrheim, Gimbsheim, Geinsheim, Eick and other unnamed localities. Breda (unpublished data) analysed additional moose teeth from the same valley, that fall in the upper size range of Cervalces. Koenigswald and Menger (1997), Koenigswald and Heinrich (1999) and Pfeiffer (1999a) date these levels which yielded mammal remains of both the cold and warm type to the Eemian and Weichselian Stages. Other authors think that the levels releasing moose remains are older (Lister and Mol, pers. comm.). In fact, mammal remains, stratigraphy and absolute dating do not rule out the existence of three levels with mammals: the upper, of glacial character and with absolute ages ranging from ca 15,000 to $43,000 \mathrm{Ka}$, is correlated with the Weichselian; the middle, of interglacial type and with absolute ages ranging from 96,000 to $133,000 \mathrm{Ka}$, can be assigned to the Eemian; the lower, of interglacial character, without absolute dating, is located on the surface of a clayey horizon (oberen Ton) recognisable in all the Upper Rhine Valley and dated from 195,000 to $274,000 \mathrm{Ka}$. Therefore, the Cervalces remains may originate from the lower level, which could be correlated with the 
penultimate interglacial (OIS 7, ca 200,000 years old). The collection, from Gross-Rohrheim, of Trogontherium cuvieri, never found in Late Pleistocene mammal assemblages, supports this hypothesis.

C. latifrons is also reported at an unknown locality in alluvial deposits near Pavia ${ }^{(52)}$ and from San Cipriano $\mathrm{Po}^{(53)}$ (Breda, 2002). The age of these remains is questionable. However the San Cipriano Po area, close to the piedmont part of the Apennines, probably sheltered pre-"Würm" deposits that, otherwise, are generally removed or covered by more recent deposits in the Po Plain. A generic Middle Pleistocene age of these two antlers is supported by their high degree of mineralisation, not comparable with that of the more recent Pleistocene remains from the Po Plain (Breda, 2002).

Schlosser (1928) reports findings of A. latifrons from Tuttlingen ${ }^{(44)}$ with a large number of dental remains and isolated proximal and distal ends of long bones. The author does not provide pictures but based on the presence of some telemetacarpals and the description of teeth a confident assignment to moose is possible. Schlosser compares the moose from Tuttlingen with the collection from Mosbach concluding they are the same size. However at Mosbach there are both $C$. carnutorum and $C$. latifrons. Since size measurements are lacking, the species identification of the remains from Tuttlingen is not possible. In any case, the presence of Mus (Schlosser, 1928) in the same deposits points to a generic Middle Pleistocene age.

The genus Alces was recorded in some late Middle Pleistocene faunas: Alces sp. 1 and 2 from Hunas ${ }^{(46)}$ (Heller and Freund, 1983; Carls et al., 1988) and A. alces from the "loess ancien moyen" of Achenheim ${ }^{(33)}$ (Wernert, 1957). The antler from Achenheim and the large part of the rich material, including several cranial and postcranial remains, from Hunas represent $C$. latifrons, because of morphology and size.

The oldest true Alces records originate from Ördöglyuck cave ${ }^{(57)}$ and Grotta Maggiore di San Bernardino 1.1. ${ }^{(55)}$.

The fauna from the Ördöglyuck cave, the origin of the holotype of $A$. brevirostris (Jánossy, 1969), was dated to just before the Late Pleistocene, i.e. to the end of the Saalian Complex, by means of evolutionary comparisons between Hungarian faunas of the first half of the late Middle Pleistocene and of Late Pleistocene age, respectively (Jánossy, 1986).

Grotta Maggiore di San Bernardino 1.1. yielded three phalanges and some other remains attributed to A. alces by Cassoli and Tagliacozzo (1994). The associated mammal assemblage, stratigraphic and evolutionary inferences and absolute dating imply that these levels should represent the penultimate glaciation (Cassoli and Tagliacozzo, 1994) The few measurements possible on the phalanges are consistent with $A$. alces.
Once the Alces record from Hattem ${ }^{(31)}$ (Erdbrink, 1954) was considered the oldest. The taxonomic placement is here confirmed, but no support is available for the Saalian age given by Erdbrink due to the lack of more recent data from the literature.

Alces becomes common in the Late Pleistocene (see, e.g., Desbrosse and Pratt, 1974; Chaix and Desse, 1981; Lister, 1984; Malez, 1986; Pfeiffer, 1999a, b; Breda, 2001c, 2002).

\section{Biochronology: Ex Soviet Union}

Excluding the dubious Pliocene and Pleistocene Alces maeoticus, Pseudalces mirandus and Tamanalces caucasicus, at present not included in the Alceini tribe (Godina, 1979, fide Sher, 1987; Heintz and Poplin, 1981; Kahlke, 1990; Breda, 2001a, b), the oldest known moose remain comes from Udunga ${ }^{(73)}$. It consists of a fragmentary frontal bone with the basal antler portion belonging to a moose slightly smaller than $C$. gallicus. The authors name it Alceinae gen. indet., although they suggest it may be a possible ancestor of the "gallicusalces" line (Vislobokova et al., 1995). Therefore we propose assignment to Cervalces sp. The rich mammal fauna from Udunga (Vislobokova et al., 1994; Vislobokova et al., 1995; Alexeeva et al., 2001) can be assigned to the Ruscinian/Villafranchian boundary, based on the presence of the earliest Mimomys stehlini and Villanyia eleonorae and the latest Pliocrocuta pyrenaica and Chasmaporthetes lunensis odessanus.

The oldest remains of $C$. gallicus come from Kuruksay 1.1. (Navrukho and Lagernaâ) ${ }^{(64)}$ and include an antler, a metatarsus and a lower jaw with $D_{2}-D_{4}$ (Vislobokova, 1986; Vangengeim et al., 1988). The antler and the metatarsus, due to morphology and size, are identified as C. gallicus. C. gallicus milk teeth are missing and thus a direct comparison with those from Kuruksay is not possible. The fauna associated with the moose remains, made up of Mammuthus $\mathrm{cf}$. gromovi and Pitymimomys cf. baschkiricus, for example, can be assigned to the Montopoli FU.

$L$. gallicus was found at Liventsovka ${ }^{(13)}$ in the uppermost level containing large mammals (Nikolskiy and Titov, 2002), which coincides to the small mammal fauna of the third level from Liventsovka, with a Mimomys pliocaenicus fauna (Aleksandrova, 1976; Tesakov, pers. comm.). The Liventsovka large mammal assemblage (Bajgusheva et al., 2001; Nikolskiy and Titov, 2002) is attributed to the Khaprovian Faunal complex. Actually this is a condensed fauna that characterises a substantial part of the Middle Villafranchian (Tesakov, pers. comm.), because of the presence of several levels containing mammals of different evolutionary level. The fauna containing the Cervalces remains and coming from the 
uppermost fossiliferous levels shows a relationship with the Costa San Giacomo FU. The moose remains consist of two antlers and some mandibles with teeth, with size within $C$. gallicus range.

At Podpusk u.1. ${ }^{(66)}$, dated to the Réunion or Olduvai Subchron, a moose shed antler beam was found (Vislobokova, 1996) which is associated with a Middle or Late Villafranchian fauna. This antler was said to resemble more closely those of C. latifrons. However it is broken below the beginning of palmation, thus it is not determinable at species level.

Foronova (1997, 1998, 2001a) describes some moose remains from the Mokhovo Suite ${ }^{(69)}$, Kuznetsk Basin. They consist of a $M_{3}$, intermediate in size between those of $C$. gallicus and $C$. latifrons, and a non-diagnostic antler basal portion. The sequence from Mokhovo gave a positive p.p. at the base, ascribed to the Olduvai Subchron, and a negative one from the upper portion bearing the mammal fauna. The fauna from Mokhovo is correlated to the Late Villafranchian, the Siberian Kizikhan Faunal Complex and the East European Odessian Faunal complex (Foronova, 1998). The small mammal assemblage and the evolutionary degree of $M$. meridionalis (Foronova, 1997, 1998, 2001a, b) suggest a correlation with the Tasso FU.

Foronova (1997, 1998, 2001a) describes a proximal portion of a large metatarsal from the Sagarlyk Suite ${ }^{(70)}$, Kuznetsk Basin, and names it $C$. aff. latifrons. The specific attribution is based on the unusually large size of the specimen. The Sagarlyk mammal fauna is assigned to the Siberian Razdolean Faunal complex and was found in pre-Jaramillo and Jaramillo layers (Foronova, 1998, 1999, 2001a, b). Prolagurus pannonicus of posterius-type, Microtus (Allophaiomys) pliocaenicus, M. meridionalis ex gr. tamanensis (=cromerensis) and Equus cf. suessenbornensis point to the Pirro Nord and Colle Curti FU.

Kozhamkulova (1974) describes a lower jaw and several isolated teeth of a large $C$. latifrons from Klochnevo ${ }^{(74)}$, suggesting they originate from the same deposits where the fauna described by Vangengeim et al., 1966 (fide Sher, 1987) was found. However, Sher points out that the fauna associated with the moose is younger than the one described by Vangengeim and suggests that it may come from the same beds of the nearby Zasukhino locality. This has been recently confirmed by Vangengeim et al. (1990), which specify the association to Zasukhino 3. The mammal assemblage found here was collected from deposits related to the end of the Matuyama Chron, around the Jaramillo Subchron. It was assigned to the Zasukhinian Faunal complex, compared with the East European Tamanian Faunal complex (Erbajeva and Alexeeva, 2000; Alexeeva et al., 2001). The presence of some taxa (e.g. Microtus
(Allophaiomys) pliocaenicus advanced form, Microtus (Stenocranius) ex gr. hintoni-gregaloides, Lycaon cf. lycaonoides, Canis variabilis - a form very close to Canis mosbachensis, according to Kahlke, 1999, Capreolus cf. suessenbornensis and Bison sp.) points to the Colle Curti FU.

Sher (1974) assigns to A. aff. latifrons an antler beam and some postcranial bones from some outcrops near the Bol'shaya Chukoch'ya River $^{(88)}$. The bones size of this moose is larger than $C$. latifrons from Western Europe and the beam proportions fall within the $C$. carnutorum range. Several other large moose remains were found in outcrops around the Bol'shaya Chukoch'ya River (Sher, 1974). This moose and the associated mammal fauna are directly and indirectly related to the beds of the Olyor Suite, which are assigned, by paleomagnetic data, to the period ranging from some times before the Jaramillo Subchron to the beginning of the Brunhes Chron (Sher, 1986). The mammal assemblage was divided into the Early Olyoran (or Chukochyan) and Late Olyoran (or Akanan) faunal complexes (Sher, 1986). The older complex is characterised by the presence of Microtus (Allophaiomys), Praedicrostonyx compitalis, Equus sp. (small-sized, archaic) and Arctelephas sp. 1, and can be assigned to the Colle Curti FU. The younger complex shows the replacement of these forms with Microtus s.s., Dicrostonyx renidens, Equus ex gr. mosbachensis and Arctelephas sp. 2, respectively, and can be related to the Slivia FU.

A fragmentary antler from Kumertau, Babaevskij quarry $^{(24)} \quad(=$ Ural, $=$ Orenburg) has been identified as C. latifrons by Yakhimovich (1965) and Boeskorov (2001), but as C. gallicus by Sher (1987) and Nikolskiy and Titov (2002) because of its slender beam. This antler shows proportions that, in our opinion, are not indicative of $C$. latifrons, while they fall within the range of those of $C$. gallicus and $C$. carnutorum. The presence of Mammuthus cf. wuesti, an archaic form of M. trogontherii (Foronova, 2001a), from the same lithostratigraphic member (Yakhimovich, 1965; Danukalova and Yakovlev, 2001) led to a hypothetical attribution of the moose remains to C. carnutorum.

In the South European area of the ex Soviet Union $C$. latifrons is a typical element of the Tiraspolian Faunal Complex. This complex, characterised by the presence of $M$. trogontherii, corresponds to the early Middle Pleistocene as meant by West and Central European authors and to the Italian Slivia, Isernia and Fontana Ranuccio FU.

Several moose remains, consisting of two fragmentary skulls with antler, several isolated antlers, mandibles with teeth and postcranials, were collected at Tiraspol $1^{(60)}$ (Pavlow, 1906; Yakhimovic, 1965; Kahlke, 1971; Sher, 1974; Svistun, 1988), the type locality of the 
homonymous Faunal complex. The layers bearing the mammal remains gave a positive p.p. correlated with the Brunhes Chron (Pevzner, 1970). The mammal assemblage is very similar to that of the Slivia FU., due to the presence of M. savini, S. hundsheimensis, Microtus (Stenocranius) gregaloides, B. schoetensacki, Equus altidens, C. elaphus, etc.

Since we lack descriptions of the moose remains from other coeval Southern European localities of the ex Soviet Union, we simply list them in the appendix (Table A2).

A later C. latifrons is recorded from Cherny $\operatorname{Jar}^{(62)}$ (=Volga River) (Kahlke, 1969; Vereshchagin, 1967a; Boeskorov, 2001, 2002), consisting in an antler beam that we consider pertaining to a young individual. Cherny Jar is the type locality of the Khazarian Faunal Complex and produced the characteristic Mammuthus chosaricus and Arvicola chosaricus (Kahlke, 1999; Markova, 1990).

In Siberia specimens similar to $C$. latifrons are reported from faunas coeval to the late Tamanian and Tiraspolian ones, because of the presence in some of them of M. trogontherii, Canis variabilis, Equus ferus $\mathrm{cf}$. mosbachensis, Equus ex gr. sanmaniensis and Praeovibos priscus (Vangengeim, 1977; Boeskorov, 2001). We confirm the species assignment of the remains from the following localities: Zagvosdinskaja ${ }^{(65)}$ (= Tobolsk region) (one antler-Pavlow, 1906; Vangengeim and Sher, 1970), Novosergeevsk ${ }^{(68)}$ (=Ob' River, Western Siberia) (some mandibles with teeth-Kahlke, 1990; Boeskorov, 2001), Yenisey ${ }^{(72)}$ (= Enisej-Bahta River area, $=$ Baht'i River, = Samarowsk) (one antler-Kahlke, 1969; Vangengeim and Sher, 1970; Kozhamkulova, 1974; Sher, 1974; Vangengeim, 1977; Kahlke, 1990), Pokrowskoe ${ }^{(77)}$ (= Lena, = Pokrovsk) (one antler-Kozhamkulova, 1974; Sher, 1974; Kahlke, 1990), Aldan-Tanda River $\operatorname{area}^{(81)}(=$ Tanda, $=$ Aldan, $4 \mathrm{~km}$ downstream on the Tandy River) (one antler-Rusanov, 1968; Kozhamkulova, 1974; Sher, 1974; Kahlke, 1990), Khara-Aldan ${ }^{(82)}$ (=Aldan) (one antler-Rusanov, 1968; Sher, 1974), Mamontova Gora ${ }^{(86)}$ (one metacarpal-Rusanov, 1968), Ulahan-Sular ${ }^{(80)}$ (one fragmentary skull with antler, three antlers, one mandible, two metatarsalsBoeskorov, 2001), Oshordoh ${ }^{(79)}$ (one fragmentary skull with antler, two antlers, four mandibles, two metatarsals-Boeskorov, 2001), Jana River ${ }^{(87)}$ (one metatarsal-Boeskorov, 2001).

The subspecies $C$. latifrons postremus was described based on an antler fragment from Mamontovaya Gora (=Aldan, =Aldan River, near Mamontova Gora, 50-m river terrace) (Sher, 1974; Kahlke, 1990; Boeskorov, 2002). Several other remains found in Siberia have been subsequently assigned to this subspecies. We confirm the taxonomic assignment to the moose remains from Tumara $^{(83)}$ (one antler-Rusanov, 1968), Tanda ${ }^{(84)}$ (one antler-Rusanov, 1968), Duvannyi Yar ${ }^{(89)}$, Koly- ma River (one antler-Boeskorov, 2002), Rossypnoe ${ }^{(85)}$ (one antler-Rusanov, 1968; Boeskorov, 2002), Mil'kovo $^{(92)}$ (=Kamchatka) (one antler-Kozhamkulova, 1974; Sher, 1974; Kahlke, 1990; Boeskorov, 2002), Malyy Anyuy River ${ }^{(90)}$, Utkinskiy quarry, in the Utkinskiy beds (one metatarsal-Sher, 1974; Vangengeim, 1977; Boeskorov, 2002), Mamontova gora ${ }^{(86)}$, $50 \mathrm{~m}$ river terrace (four antlers-Rusanov, 1968; Boeskorov, 2001, 2002), Bol'shaya Chukoch'ya River ${ }^{(88)}$, in the Utkinskiy beds (one antler-Sher, 1974; Boeskorov, 2001, 2002), Ulahan Sullar ${ }^{(80)}$ (one antler-Boeskorov, 2001, 2002), Oshordoh ${ }^{(79)}$ (some teeth-Boeskorov, 2001), Lena River delta ${ }^{(78)}$ (one antler-Boeskorov, 2001, 2002), Northern Yakutia ${ }^{(91)}$ (one antler-Boeskorov, 2001, 2002), Verkhnevilyuiskoe ${ }^{(76)}$ (=Vilyui River, upper level) (three antlers and one skull fragment with incomplete antler-Boeskorov, 2001, 2002), Krasnyj Jar, Ob' River ${ }^{(67)}$ (some antlers-Kahlke, 1990; Boeskorov, 2001, 2002; Shpanskij, 2003). The mammal assemblage (when present) found with the moose remains consists of Mammuthus primigenius early type, Bison priscus, Equus orientalis, Megaloceros giganteus, Ursus rossicus, Lagurus lagurus and Arvicola terrestris. M. primigenius early type is the type species for the Early Mammoth Faunal complex, which is the analogue of the end of the Italian Vitinia FU. This Faunal complex is correlated, by many authors, with the last Middle Pleistocene glaciation (OIS 6) (Chlachula, 2001; Foronova, 2001a; Lister and Sher, 2001), named as Tazovian glacial in Siberia.

The earliest Alces record is from the Chernigovo Suite ${ }^{(71)}$, Kuznetsk Basin, in a fauna (M. primigenius early type, Stephanorhinus sp., Gulo gulo, etc.) related to the Tazovian glacial (Foronova, 2001a). The moose remains consist of postcranials and of an antler of the same size as living moose.

Another early Alces record is from Lower Tungusk ${ }^{(75)}$ (V and IV terrace) (one metatarsal-Sher, 1974; Vangengeim, 1977). The associated mammal assemblage (M. primigenius early type, B. priscus, Equus caballus large type) is, again, of Tazovian period (Vangengeim, 1977).

A. alces with typical antlers and cranial remains is known to have existed during the first half of the Late Pleistocene, for example, in the western Transcaucasian caves, along with mammal assemblages of forest and Mediterranean type (Sher, 1987), in the southern Siberian loess region (Chlachula, 2003) and in the lower levels of the Bahatsk Suite (south of Western Siberia, Kuznetsk Basin) (Foronova, 2001a). During the second half of the Late Pleistocene Alces becomes widespread in the ex Soviet Union (Vereshchagin, 1967b; Sher, 1987; Foronova, 2001a).

The chronological distribution of the localities bearing fossil moose specimens has been summarised in Fig. 6. 


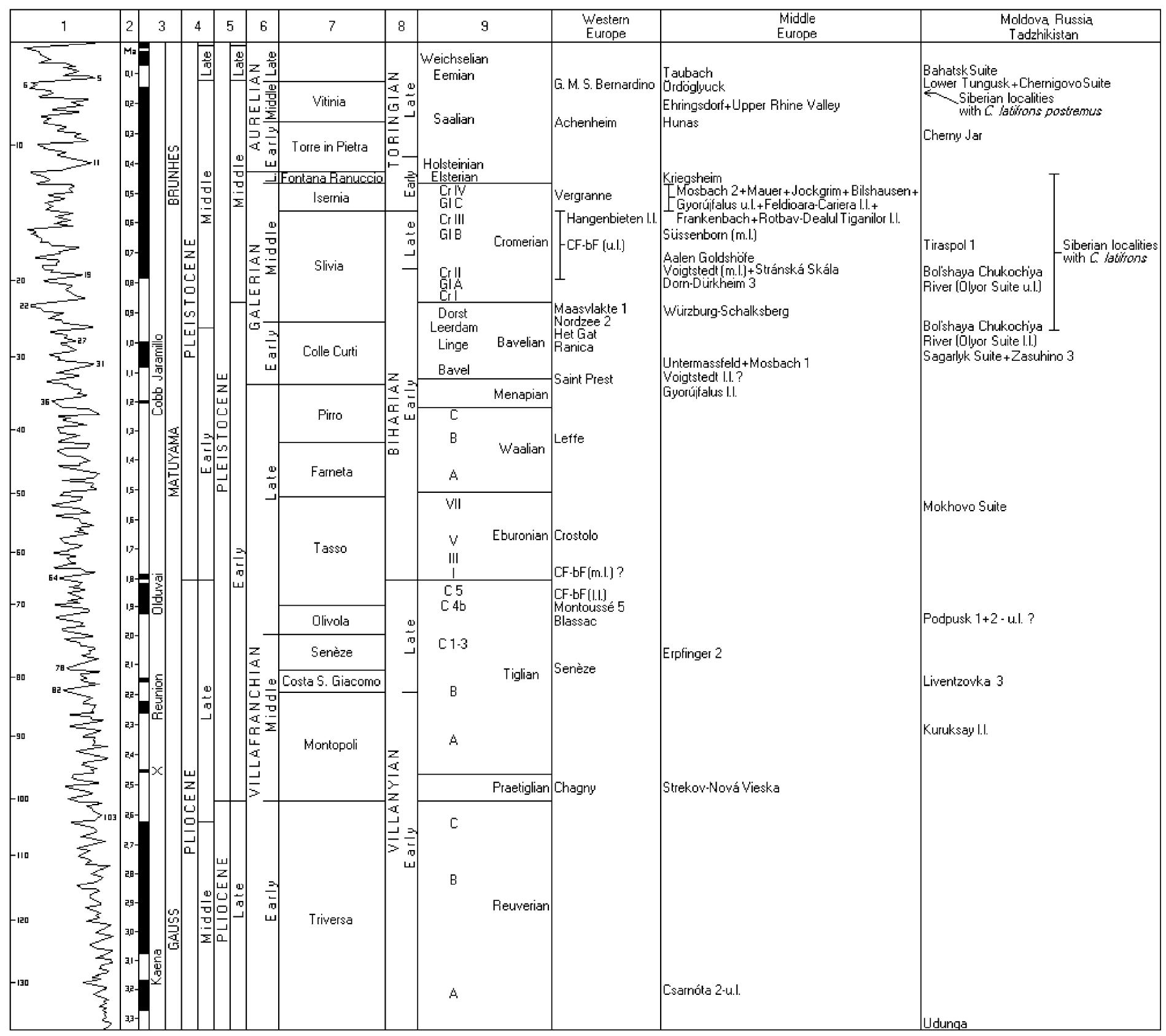

Fig. 6. Biochronological scheme of Plio-Pleistocene Eurasian localities with Cervalces and earliest Alces. (1) ${ }^{18}$ O curve (Shackleton, 1995); (2) Absolute ages; (3) Magnetostratigraphy; (4) Geochronology (sensu Gliozzi et al., 1997); (5) Geochronology (sensu Gibbard et al., 1991); (6) Italian Large Mammal Ages (Gliozzi et al., 1997, modified); (7) Italian Faunal Units (Gliozzi et al., 1997); (8) Small Mammal Ages of West and Central Europe (Fejfar et al., 1998); (9) Floristic Complexes of Northern Europe (Gibbard et al., 1991). 


\section{Results and discussion}

The European Cervalces remains have been attributed to the different species based on their size and on the proportions of their antlers. This is possible because the geographical proximity to the type localities suggests a rather homogeneous distribution, with a reduced range of variability in size and morphology within one species. As a result, size and antler proportions may be sufficient to infer a species affiliation. In the dispersion graph in Fig. 7, beam length, from the burr to the beginning of palmation, is plotted against beam circumference just above the burr, to represent the antler proportions.

The specific identification is more difficult for the Siberian material that, owing to its distance from the type localities, cannot be assumed to strictly correspond to the coeval European populations in size and morphology. Indeed, the wide geographic range may result in greater morphological and/or size differences. Therefore, caution must be exercised in direct comparisons of size and/or proportions with the type specimens. In Fig. 8, we plot antler dimensions in the same kind of dispersion graph used for the European remains.

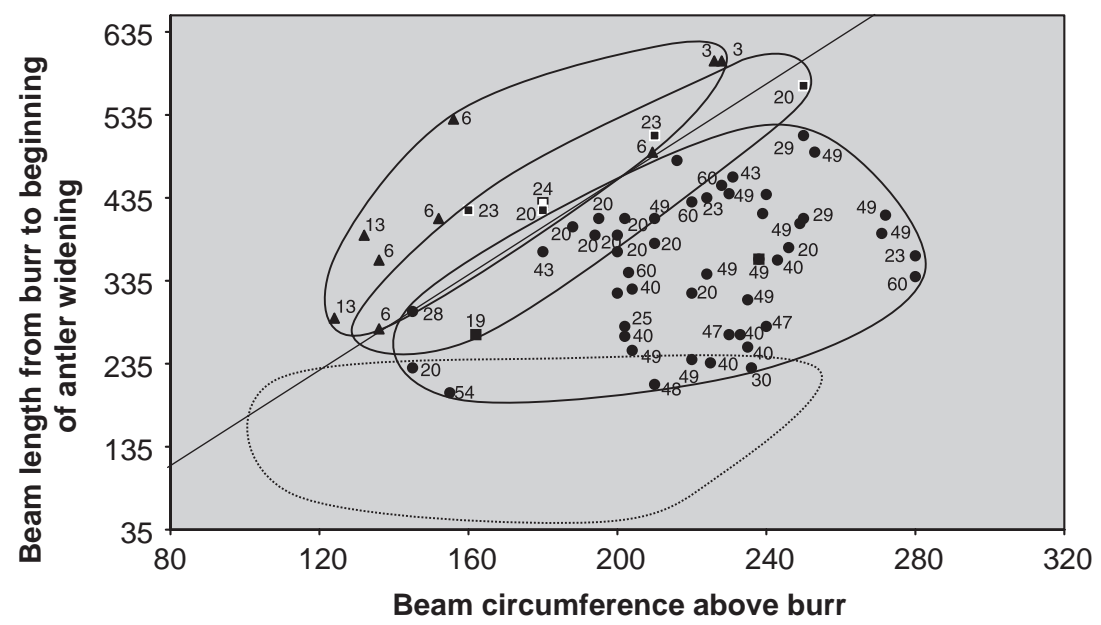

Fig. 7. Dispersion graph of beam length (from burr to beginning of palmation) plotted against beam circumference (just above the burr) of the European fossil Alceini. The antlers from each site are represented by the same simbols used in Figs. 2-4 and by the number identifying the site as listed in Table 1. The straight line parts the antlers attributable to C. gallicus (above) from those attributable to C. latifrons (below). The dispersion ranges of these species and of the intermediate $C$. carnutorum are tentatively represented by three full lines. The range of $A$. alces is represented by the dotted line at the bottom of the diagram (measurements taken from 61 antler remains from North America, Siberia, Scandinavia and Upper Rhine Valley of Last Glacial and Holocene age after Battaglia, 1961, Pfeiffer, 1999a and Boeskorov, 2002).

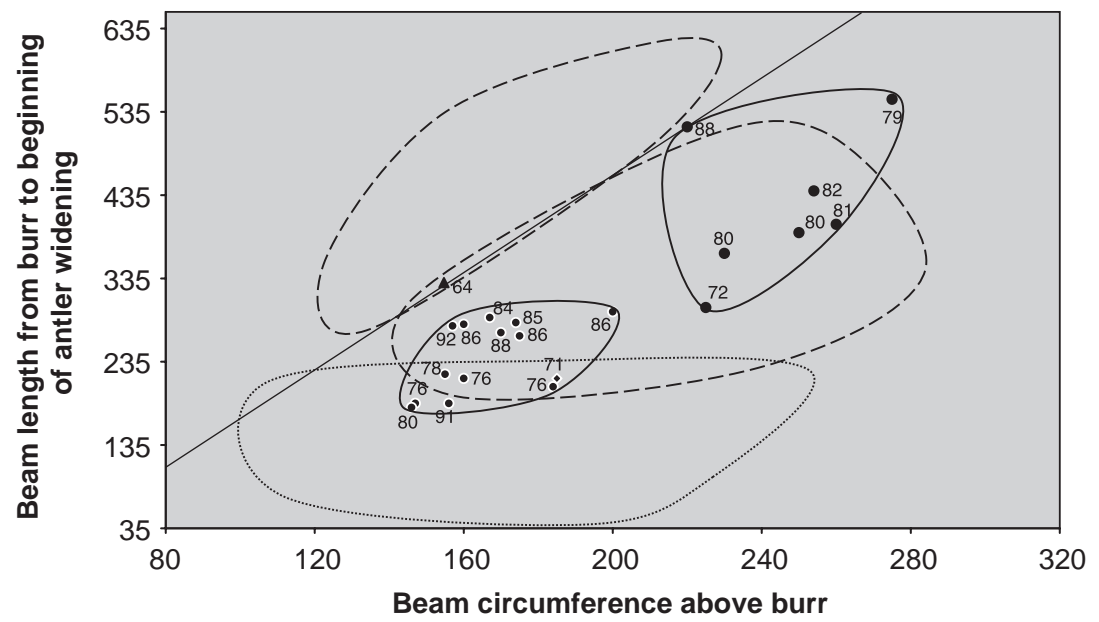

Fig. 8. Dispersion graph of beam length (from burr to beginning of palmation) plotted against beam circumference (just above the burr) of the Asian fossil Alceini. The antlers from each site are represented by the same simbols used in Fig. 5 and by the number identifying the site as listed in Table 1 . The full lines represent, respectively, the C. latifrons latifrons (above, right) and C. latifrons postremus (below, left) from Asia, while the hatched lines represent, for comparison, the range of the $C$. gallicus (above, left) and $C$. latifrons (below, right) from Europe. The range of $A$. alces is represented by the dotted line at the bottom of the diagram (measurements as in Fig. 7). 
Comparison with Fig. 7 reveals that the Siberian moose antlers from the Early- and early Middle Pleistocene have the same proportions. In contrast, the postcranials from Siberia of the same age are sometimes larger than the European coeval ones. Several Russian researchers already observed this difference in size and recorded it as C. aff. latifrons or Cervalces sp. nov.

Nikolskiy (1997) suggests that the older C. latifrons remains from Western and Eastern Beringia can be separated into two groups: a primitive form from the Lower Olyorian levels (Early Pleistocene), larger than the European $C$. latifrons, with longer and more slender antler beams and a low molarised $P_{3}$ (antler and $P_{3}$ structure should place this form close to C. gallicus); an advanced form from the Upper Olyorian deposits (early Middle Pleistocene), of the same size of the European $C$. latifrons, with antler beams of the same proportions and a more molarised $P_{3}$ (all characters similar to the coeval European forms).

Data from the literature on the Siberian remains is not enough to test the assumption made by Nikolskiy. Nonetheless, it is worthy of note that Sher $(1974,1986)$, in contrast, relates the remains of the typical C. latifrons size and morphology to the Lower Olyorian and those of larger size and longer beams, that he calls $C$. aff. latifrons, to the Upper Olyorian. Foronova (1998) quotes this large $C$. aff. latifrons from the Kuznetsk Basin, in the Sagarlik Suite, as well.

Regarding molarisation of $P_{3}$, Kahlke (1956) reports that the lingual wall is open in the $C$. gallicus remains from the CF-bF while para- and metastilyd are connected, closing the lingual wall in the $C$. latifrons from the same CF-bF. Mäuser (1990) suggests that in the Alceini evolutionary lineage the degree of molarisation of $P_{3}$ depends on the stratigraphic age, because it increases from C. gallicus to C. latifrons. Pfeiffer (1999a) maintains that this character is too variable among deer to be considered an evolutionary tendency of the Alceini tribe and Breda (2001a) points out that the holotype of C. gallicus does not confirm the hypothesis made by Mauser, showing the parastylid connected to the metastylid.

We conclude that there is no reason to regard C. aff. latifrons more than a local population of the European $C$. latifrons, since in Siberia, at the end of the Early Pleistocene and in the early Middle Pleistocene, there are both remains in the size range of the European C. latifrons (e.g. Süssenborn) and larger specimens. This means that there is a shift in the size range of the Siberian moose with respect to the European moose, but the large overlap in size between the two prevents a separation into distinct species. The existence of a cline in size range of $C$. latifrons is a more plausible explanation, since the lack of geographical barriers could not have given rise to speciation. One possible interpretation is that $C$. latifrons attained a larger size in its eastern range due to different living condition, such as better food availability (optimal conditions), or colder environment (as predicted by the Bergman's rule), or a more open habitat (advantage in escaping from predators).

Our analysis of the literature gives another interesting result. Foronova (1998, 2001a) describes Cervalces sp. from the Kuznetsk Basin, in the Mokovo Suite, represented by a juvenile antler, which is inadequate for the species identification, and some teeth of small size. This could be the first record of $C$. carnutorum outside of Europe. The Late Villafranchian date corresponds well with that of the European $C$. carnutorum.

As for C. latifrons postremus, we believe that this subspecies is present in Siberia, while, to date, there are no data supporting its existence in Europe. As suggested by Pfeiffer (1999a), the European antlers attributed to C. latifrons postremus could belong to young specimens of typical $C$. latifrons, since there are also long and strong antlers (adults) from the same deposits (Fig. 7). In contrast, in Siberia, antlers with long and robust beams are recorded from nearly the entire Middle Pleistocene, but in the latest Middle Pleistocene deposits only smaller and slender beams were found (Fig. 8). Therefore, this cannot be a coincidence since the latest Middle Pleistocene moose from Siberia have antlers that can be distinguished from those of the European $C$. latifrons and, consequently, the sub-specific distinction is justified.

However, we reject the hypothesis, reported by many authors (Kahlke, 1990; Nikolskiy, 1997; Boeskorov, 2002), that the subspecies C. latifrons postremus was intermediate in size between $C$. latifrons and $A$. alces. In fact, this idea resulted from considering only the intermediate antler dimensions of the type specimen, and later, was reinforced by Sher (1974) who described the metatarsal bone from Malyy Anyuy River as smaller than $C$. latifrons. Unfortunately, in the size comparison, Sher used the $C$. latifrons metatarsal from Bol'shaya Chukoch'ya River, which is the largest among all the known Cervalces. Indeed, the author pointed out that the metatarsus from Malyy Anyuy River was similar in size to C. latifrons from Tiraspol, and we can confirm that this metatarsus falls within the range size of typical C. latifrons from Western Europe. This difficulty in interpreting the Russian literature on size indications for the specimens is a recurrent problem, since comparisons are alternatively made with the West European and the Russian specimens in the Russian studies.

Nikolskiy (1997) points out that the metatarsal bone from Malyy Anyuy River is the only moose postcranial remain which can be certainly associated with the late Middle Pleistocene deposits, the 


\begin{tabular}{|c|c|c|c|c|c|c|c|}
\hline Age & $\begin{array}{l}\text { Anatomical } \\
\text { portions }\end{array}$ & Europe & & Kuznetsk Basin & & \begin{tabular}{|l|} 
Central and \\
Eastern Siberia
\end{tabular} & \\
\hline $\begin{array}{l}\text { Late Pleistocene } \\
(0.1-0 \mathrm{Ma})(\mathrm{OIS} 5-1)\end{array}$ & $\begin{array}{l}\text { Beam } \\
\text { Limb bones } \\
\text { Teeth }\end{array}$ & Alces alces & $\begin{array}{l}\text { very short } \\
\text { small } \\
\text { small }\end{array}$ & Alces alces & $\begin{array}{l}\text { very short } \\
\text { small } \\
\text { small }\end{array}$ & Alces alces & $\begin{array}{l}\text { very short } \\
\text { small } \\
\text { small } \\
\end{array}$ \\
\hline $\begin{array}{l}\text { end of Middle Pleistocene } \\
\text { (ca. 0.14 Ma) (late OIS 6) }\end{array}$ & $\begin{array}{l}\text { Beam } \\
\text { Limb bones } \\
\text { Teeth }\end{array}$ & cf. Alces sp. & $\begin{array}{l}\text { very short } \\
\text { small } \\
\text { small } \\
\end{array}$ & cf. Alces sp. & $\begin{array}{l} \\
\text { small } \\
? \\
\end{array}$ & cf. Alces sp. & $\begin{array}{l}\text { ? } \\
\text { small } \\
? \\
\end{array}$ \\
\hline $\begin{array}{l}\text { end of Middle Pleistocene } \\
\text { (ca. 0.17 Ma) (early OIS 6) }\end{array}$ & $\begin{array}{l}\text { Beam } \\
\text { Limb bones } \\
\text { Teeth }\end{array}$ & & & C. l. postremus & $\begin{array}{l}\text { short } \\
? \\
? \\
\end{array}$ & C. l. postremus & $\begin{array}{l}\text { short } \\
\text { large } \\
\text { large } \\
\end{array}$ \\
\hline $\begin{array}{l}\text { early Middle Pleistocene } \\
(0.9-0.2 \mathrm{Ma}) \text { (OIS 24-7) }\end{array}$ & $\begin{array}{l}\text { Beam } \\
\text { Limb bones } \\
\text { Teeth }\end{array}$ & C. latifrons & $\begin{array}{l}\text { medium } \\
\text { large } \\
\text { large }\end{array}$ & & & C. latifrons & $\begin{array}{l}\text { medium } \\
\text { large } \\
\text { large } \\
\end{array}$ \\
\hline $\begin{array}{l}\text { late Early Pleistocene } \\
(1.05-0.9 \mathrm{Ma})(\mathrm{OIS} 30-25)\end{array}$ & $\begin{array}{l}\text { Beam } \\
\text { Limb bones } \\
\text { Teeth }\end{array}$ & C. latifrons & $\begin{array}{l}\text { medium } \\
\text { large } \\
\text { large }\end{array}$ & C. latifrons & $\begin{array}{l}\text { ? } \\
\text { large to very large } \\
?\end{array}$ & C. latifrons & $\begin{array}{l}\text { medium-long } \\
\text { large-very large } \\
\text { large-very large }\end{array}$ \\
\hline $\begin{array}{l}\text { early Early Pleistocene } \\
(1.8-1.05 \mathrm{Ma})(\text { OIS 64-31) }\end{array}$ & $\begin{array}{l}\text { Beam } \\
\text { Limb bones } \\
\text { Teeth }\end{array}$ & C. carnutorum & $\begin{array}{l}\text { long } \\
\text { medium } \\
\text { medium }\end{array}$ & C. cf. carnutorum & $\begin{array}{l}? \\
? \\
\text { medium } \\
\end{array}$ & & \\
\hline $\begin{array}{l}\text { Late Pliocene } \\
(2.55-1.8 \mathrm{Ma}) \text { (OIS 100-65) }\end{array}$ & $\begin{array}{l}\text { Beam } \\
\text { Limb bones } \\
\text { Teeth }\end{array}$ & C. gallicus & $\begin{array}{l}\text { very long } \\
\text { small } \\
\text { small }\end{array}$ & & & & \\
\hline
\end{tabular}

Fig. 9. Schematic comparison among the size (postcranials and teeth) and the beam proportions of coeval Cervalces and Alces records from different geographical regions. The European type species, on the left column, are regarded as the reference for both size and proportion.

Utkinsky beds, where a typical C. latifrons postremus antler originates, too. Few other postcranial bones of that size from Western Beringia, which are speculatively related to the late Middle Pleistocene, were found by the author.

The comparison of size and beam proportion among the Cervalces and Alces remains from the different geographical regions has been summarised in Fig. 9.

\section{Conclusions}

The biochronological analysis of the localities yielding moose remains enables us to outline a hypothetical framework for the geographical and chronological distribution of this group.

The representatives of the Alceini tribe appear at the Ruscinian/Villafranchian boundary with few and fragmentary remains, inadequate for species identification. During the Middle Villafranchian, with $C$. gallicus, the tribe spreads in the whole Eurasia. In the course of the Late Villafranchian, C. gallicus evolves into C. carnutor$u m$ (keeping the taxonomical reserves given above), which subsequently develops into $C$. latifrons some times after the Villafranchian/Galerian boundary. The last known $C$. latifrons are reported for the penultimate interglacial (OIS 7). C. l. postremus and the oldest Alces records are both dated to the penultimate glaciation (OIS 6). This datum suggests that the substitution between Cervalces and Alces occurred during the last cold phase of the Middle
Pleistocene, i.e. during the last cold period of the North European Saalian glacial and the Siberian Tazovian glacial, which are correlated with the OIS 6. C. latifrons postremus has only been found in Siberia so far. A moose close to Alces genus and recorded with fragmentary and badly known remains, replaced Cervalces. A. alces appears in the Late Pleistocene. The chronological distribution of the fossil moose species has been summarised in Fig. 6, where the moose bearing localities have been located in the biochronological scheme adopted in this work.

Our analysis shows that $A$. alces does not evolve from the last Western European representatives of the genus Cervalces. It is easier to accept the hypothesis that the living moose species derived from some Eastern European or Asiatic forms. Furthermore, most researchers accept the idea that majority of the present European mammals are of Asian origin. C. latifrons postremus or A. brevirostris could be possible ancestors of living moose, based on their age and intermediate morphology between $C$. latifrons and A. alces. Therefore, the origin of present-day moose is an open question, at least until cranial remains with intermediate facial portion, other than the one from Ördöglyuck, is found, confirming that the only existing is not a teratological specimen.

\section{Appendix A}

See Tables A1 and A2. 
Geographical indications of the analysed sites

\begin{tabular}{|c|c|c|c|c|}
\hline & Locality & Nation & Geography & Taxonomic allocation \\
\hline 1 & Montoussé 5 & France & Midi-Pyrénées R.-Hautes-Pyrénées D.-SE Tarbes-n. Labarthe-de-Neste & C. gallicus \\
\hline 2 & Blassac-la-Girondie & France & Auvergne R.-Haute-Loire D.-W/NW Le Puy-14 km S Brioude & Cervalces sp. \\
\hline 3 & Senèze & France & Auvergne R.-Haute-Loire D.-W/NW Le Puy & C. gallicus \\
\hline 4 & Chagny and Perrigny & France & Bourgogne R.-Saône-et-Loire D.-N Mâcon-NW Chalon-sur-Saône & Cervalces sp. and Cervidae indet. \\
\hline 5 & Dogger Bank & Great Britain & England-Norfolk-90 km E Northumberland coast & C. gallicus, C. latifrons \\
\hline 6 & East Runton & Great Britain & England-Norfolk-N Norwich & C. gallicus \\
\hline 7 & Sidestrand & Great Britain & England-Norfolk-N Norwich & C. gallicus, $C$. cf. carnutorum, C. latifrons \\
\hline 8 & Overstrand & Great Britain & England-Norfolk-N Norwich & C. gallicus, $C$. cf. carnutorum, C. latifrons \\
\hline 9 & Erpfingen 2 & Germany & Baden-Württemberg R. $-50 \mathrm{~km}$ S Stuttgart-Schwabische Alb-n. Tübingen & C. gallicus \\
\hline 10 & Strekov \& Nová Vieska & Slovakia & Western Slovakia R.-Západoslovenský P.-E Bratislava-n. Nové Zámky & C. gallicus \\
\hline 11 & Csarnóta 2 u.l. & Hungary & Baranya P.-S Pécs-n. Siklós-Villány Mountains & Alceini indet. \\
\hline 12 & Prundu & Romania & Ilfov County-S Bucarest-NE Giurgiu & C. gallicus \\
\hline 13 & Liventsovka & Russia & Rostovskaya P.-W Rostov-na-Donu-n. Rostov-na-Donu-Don Basin & C. gallicus \\
\hline 14 & Cromer & Great Britain & England-Norfolk-N Norwich & C. cf. carnutorum, C. latifrons \\
\hline 15 & Walcott & Great Britain & England-Norfolk-NE Norwich & C. cf. carnutorum \\
\hline 16 & Mundesley & Great Britain & England-Norfolk-N Norwich & C. cf. carnutorum, C. latifrons \\
\hline 17 & Saint-Prest & France & Centre R.-Eure-et-Loir D.-N Chartres-Eure valley & C. carnutorum \\
\hline 18 & Leffe & Italy & Lombardia R.-N Bergamo-n. Albino & C. carnutorum \\
\hline 19 & Il Crostolo & Italy & Emilia Romagna R.-SW Reggio Emilia & C. carnutorum \\
\hline 20 & Mosbach $1+2$ & Germany & Hessen R.-n. Wiesbaden & C. cf. carnutorum, C. latifrons \\
\hline 21 & Untermassfeld & Germany & Thüringen R.-W Suhl-n. Meiningen & C. carnutorum \\
\hline 22 & Voigtstedt 1.1. + m.1. & Germany & Thüringen R.-N/NE Erfurt-n. Artern-15 km S Sangerhausen & C. carnutorum, C. latifrons \\
\hline 23 & Győrújfalu & Hungary & Györ-Moson-Sopron P.-N Győr-n. Győr & C. cf. carnutorum, C. latifrons \\
\hline 24 & Kumertau, Babaevskij quarry & Russia & Orenbourg P.-100 km N Orenburg-Southern Urali-n. Kumertau & Cervalces carnutorum? \\
\hline 25 & Happisburg & Great Britain & England-Norfolk-NE Norwich & C. latifrons \\
\hline 26 & Trimingham & Great Britain & England-Norfolk-N Norwich & C. latifrons \\
\hline 27 & West Runton & Great Britain & England-Norfolk-N Norwich & C. latifrons \\
\hline 28 & Pakefield & Great Britain & England-Suffolk-NE Ipswich-n. Lowestoft & C. latifrons \\
\hline 29 & Nordzee 2 & The Netherlands & Bottom of North Sea between Netherlands and England & C. latifrons \\
\hline 30 & Het Gat & The Netherlands & Bottom of North Sea between The Netherlands and England & C. latifrons \\
\hline 31 & Hattem & The Netherlands & Gelderland-N Arnhem-n. Zwolle & Alces sp. \\
\hline 32 & Maasvlakte 1 & The Netherlands & Zuid-Holland-SW 's-Gravenhage & C. latifrons \\
\hline 33 & Achenheim & France & Alsace R.-Bas-Rhin D.-n. and W Strasbourg & C. latifrons \\
\hline 34 & Hangenbieten & France & Alsace R.-Bas-Rhin D.-n. Strasbourg & C. latifrons \\
\hline 35 & Mietersheim & France & Alsace R.-Bas-Rhin D.--N Strasbourg-n. Reichshoffen & C. latifrons \\
\hline 36 & Vergranne & France & Bourgogne R.-Doubs D.-NE Besançon-7 km N Baume-les-Dames & C. latifrons \\
\hline 37 & Jockgrim & Germany & Rheinland-Pfalz R.-S Mainz-13 km NW Karlsruhe & C. latifrons \\
\hline 38 & Dorn-Dürkheim 3 & Germany & Rheinland-Pfalz R.-S Mainz-17 km N/NW Worms & C. latifrons \\
\hline 39 & Kriegsheim & Germany & Rheinland-Pfalz R.-S Mainz-ca $10 \mathrm{~km} \mathrm{~W} \mathrm{Worms}$ & C. latifrons \\
\hline 40 & Upper Rhine Valley & Germany & Rheinland-Pfalz R.-S/SE Wiesbaden-between Mainz and Worms & C. latifrons \\
\hline 41 & Aalen Goldshöfe & Germany & Baden-Württemberg R.-E Stuttgart-n. Aalen & C. latifrons \\
\hline 42 & Frankenbach & Germany & Baden-Würtenberg R.-N Stuttgart-n. Heilbronn & C. latifrons \\
\hline 43 & Mauer & Germany & Baden-Württemberg R.-N/NW Stuttgart-n. Heidelberg & C. latifrons \\
\hline 44 & Tuttlingen & Germany & Baden-Württemberg R.-S Stuttgart & Cervalces sp. \\
\hline 45 & Würzburg-Schalksberg & Germany & Bayern R.-N/NW München-n. Würzburg & C. latifrons \\
\hline
\end{tabular}




\begin{tabular}{|c|c|c|c|c|}
\hline 46 & Hunas & Germany & Bayern R.-N München-n. Hersbruck & C. latifrons \\
\hline 47 & Bilshausen & Germany & Niedersachsen R.-S Hannover-NE Göttingen-n. Lindau & C. latifrons \\
\hline 48 & Ehringsdorf & Germany & Thüringen R.-E Erfurt-n. and SE Weimar & C. latifrons \\
\hline 49 & Süssenborn m.l. & Germany & Thüringen R.-E Erfurt-n. Weimar & C. latifrons \\
\hline 50 & Taubach & Germany & Thüringen R.-E Erfurt-n. and SE Weimar & Cervidae indet. \\
\hline 51 & Stránská Skála & Czech Republic & Southern Moravia R.-Jihomoravský P.-S Brno & C. latifrons \\
\hline 52 & alluvium n. Pavia & Italy & Lombardfia R.-S Milano & C. latifrons \\
\hline 53 & San Cipriano Po & Italy & Lombardfia R.-S Milano-NW Pavia & C. latifrons \\
\hline 54 & Ranica & Italy & Lombardia R.-NE Milano-n. Bergamo & C. latifrons \\
\hline 55 & Grotta Maggiore di S. Bernardino 1.1. & Italy & Veneto R.-S Vicenza-Berici Hills & Alces sp. \\
\hline 56 & Vič Terrace & Slovenia & Lubjana & C. latifrons \\
\hline 57 & Ördöglyuck & Hungary & Pest Megye-N Budapest-n. Solymar & A. brevirostris \\
\hline 58 & Feldioara-Cariera 1.1. & Romania & Braşov County-N Braşov-n. Feldioara & C. latifrons \\
\hline 59 & Rotbav-Dealul Tiganilor 1.1. & Romania & Braşov County-n. Braşov & C. latifrons \\
\hline 60 & Tiraspol 1 & Moldova & Bessarabya-ca $60 \mathrm{~km}$ SE Chishinev-Dnester Basin & C. latifrons \\
\hline 61 & Routa River & Russia & Tula P.-n. Tula & A.alces \\
\hline 62 & Missa & Russia & Tatarsan P.-n. Kazan-Kama River & A.alces \\
\hline 63 & Cherny-Jar & Russia & NW Astrakhan-Volga River Basin & C. latifrons \\
\hline 64 & Kuruksay 1.1. & Tadzhikistan & Western Tadzhikistan-18 km NE Baldzhuan-Afghan-Tadzik Depression & C. gallicus \\
\hline 65 & Zagvosdinskaja & Russia & Western Siberia-n. Tobolsk-Irtysh River Basin & C. latifrons \\
\hline 66 & Podpusk u.l. & Russia & Western Siberia-S Pavlodar-Irtysh River & Cervalces sp. \\
\hline 67 & Krasnyj Jar & Russia & Western Siberia-NE Novosibirsk-Ob' River & C. latifrons postremus \\
\hline 68 & Novosergeevsk & Russia & Western Siberia-n. Kemerovo-Ob' River Basin & C. latifrons \\
\hline 69 & Mokhovo Suite & Russia & south of Western Siberia-Kuznetsk Basin & C. cf. carnutorum \\
\hline 70 & Sagarlyk Suite & Russia & south of Western Siberia-Kuznetsk Basin & C. latifrons \\
\hline 71 & Chernigovo Suite & Russia & south of Western Siberia-Kuznetsk Basin & A. cf. alces \\
\hline 72 & Yenisey & Russia & Central Siberia-Yenisey River basin downstream Bachta River mouth & C. latifrons \\
\hline 73 & Udunga & Russia & Central Siberia-Transbaikalia-Temnik River, tributary of the Selenga River & Cervalces sp. \\
\hline 74 & Klochnevo & Russia & Central Siberia-Transbaikalia-N Ulan-Ude-Itantza River & C. latifrons \\
\hline 75 & Lower Tungusk & Russia & Central Siberia-Tungusk River & Alces sp. \\
\hline 76 & Verkhnevilyuiskoe & Russia & Central Siberia-n. Verchnevilyuisk-tributary of Lena River & C. latifrons postremus \\
\hline 77 & Pokrowskoe & Russia & Central Siberia-S/SW Jakutsk-Lena River & C. latifrons \\
\hline 78 & Lena River delta & Russia & Central Siberia & C. latifrons postremus \\
\hline 79 & Oshordoh & Russia & Central Siberia-Jana River Basin-Adycha River & C. latifrons, C. latifrons postremus \\
\hline 80 & Ulahan-Sular & Russia & Central Siberia-Jana River Basin-Adycha River & C. latifrons, C. latifrons postremus \\
\hline 81 & Aldan-Tanda River area & Russia & Eastern Siberia-NE Jakutsk & C. latifrons \\
\hline 82 & Khara-Aldan & Russia & Eastern Siberia-NE Jakutsk-Aldan River & C. latifrons \\
\hline 83 & Tumara & Russia & Eastern Siberia-NE Jakutsk-Aldan River & C. latifrons postremus \\
\hline 84 & Tanda & Russia & Eastern Siberia-NE Jakutsk-Aldan River & C. latifrons postremus \\
\hline 85 & Rossypnoe & Russia & Eastern Siberia-NE Jakutsk-Aldan River & C. latifrons postremus \\
\hline 86 & Mamontova gora & Russia & Eastern Siberia-E/NE Jakutsk-Aldan River & C. latifrons, C. latifrons postremus \\
\hline 87 & Jana River & Russia & Eastern Siberia-E Batagaj & C. latifrons \\
\hline 88 & Bol'shaya Chukoch'ya River & Russia & Eastern Siberia-Kolyma Lowlands & C. latifrons, C. latifrons postremus \\
\hline 89 & Duvannyi Yar & Russia & Eastern Siberia-Kolyma Lowlands-Kolyma River-n. Cherskiy & C. latifrons postremus \\
\hline 90 & Malyy Anyuy River, Utkinskiy quarry & Russia & Eastern Siberia-Kolyma Lowlands-SE Cherskiy & C. latifrons postremus \\
\hline 91 & Northern Yakutia & Russia & Eastern Siberia-Kolyma Lowlands-E Anyusk & C. latifrons postremus \\
\hline 92 & Mil'kovo & Russia & Eastern Siberia-Kamchatka-Kamchatka River & C. latifrons postremus \\
\hline
\end{tabular}

The numbering on the left of the table is the reference number used in the location maps (Figs. 2-5), in the dispersion graphs of the antler proportions (Figs. 7 and 8 ) and in the text. Abbreviations: R. = Region; D. = Department; P. = Province; $\mathrm{n} .=$ near. 
Table A2

Geographical indications and bibliographic references of all the Middle Pliocene to Middle Pleistocene moose records for which identification cannot be confirmed due to lack of data (descriptions,

measurements, pictures)

\begin{tabular}{|c|c|c|c|}
\hline Locality & Nation & Geography & Taxonomic allocation and references \\
\hline Maasvlakte 0 & The Netherlands & Zuid-Holland-SWs-Gravenhage & Alces cf. gallicus (Kolfschoten, 2001) \\
\hline Csarnóta 1 & Hungary & Baranya P.-S Pécs-n. Siklós & Alces sp. (Kretzoi, 1956) \\
\hline Turnu Severin & Romania & Mehedinţhi County-Drobeta-Turnu Severin & Libralces gallicus (Marcović-Marjanović, 1970) \\
\hline Valea Mijlociei & Romania & Vîlcea County-SW Rîmnicu-Vîlcea-n. Tetoiu & Alces gallicus (Rădulescu and Samson, 2001) \\
\hline Krizhanovka u.l. & Ukraine & Odesskaya P.-n. Odessa-Dnester Basin & Alces sp. (Dubrovo and Kapelist, 1979) \\
\hline Kushkuna 1.1. & Georgia & Western Georgia & Alces s.l. sp.(Wiegank, 1983) \\
\hline Saint-Martial & France & Languedoc-Roussillon R.-Hérault D.-W Sète-n. Pézenas & Cervus alces $=C$. martialis $($ Owen, 1869; Mayet and Roman, 1923) \\
\hline Żabia Cave & Poland & Katowice Voivodate-E Katowice-Podlesice n. Kroczyce & Libralces gallicus (Czyżewska, 1989) or L. carnutorum (Kahlke, 1990) \\
\hline Osztramos 2 & Hungary & Borsod-Abaúj-Zemplén P.-50 km N Miskolc & Cervus s.l. sp. II (gr. Alces) (Jánossy, 1986) \\
\hline Betfia $5,7 / 3 b, 7 / 4 a$ and $7 / 4 b$ & Romania & Bihor County-n. Oradea & Prealces latifrons (Terzea, 1994) \\
\hline Valea Ripei & Romania & Vîlcea County-SW Rîmnicu-Vîlcea-n. Tetoiu- Dacic Basin & Prealces cf. carnutorum (Rădulescu and Samson, 1990) \\
\hline Zhevakova Gora u.l. & Ukraine & Odesskaya P.-n. Odessa-Kujalynickij Liman & Alces sp. (Alekseeva, 1977) \\
\hline Kaiafas & Greece & Peloponnesus-Eleía-ca $20 \mathrm{~km}$ SE Pyrgos & Cervalces cf. latifrons (Koufos, 2001) \\
\hline Rhenen & The Netherlands & Utrecht P.-SE Utrecht & Alces latifrons (Guérin, 1980) \\
\hline Montreuil & France & Íle-de-France Department-Paris & Alces sp. (Guérin, 1980) \\
\hline Miesenheim 1 & Germany & Rheinland-Pfalz R.-NW Mainz-n. Andernach & Alces sp. (Koenigswald, 1995) \\
\hline Kärlich Gb & Germany & Rheinland-Pfalz R.-NW Mainz-n. Koblenz & Alces sp. (Rothausen, 1970; Koenigswald and Heinrich, 1999) \\
\hline Leimersheim & Germany & Rheinland-Pfalz R.-S Mainz-n. Rülzheim & A. latifrons (Soergel, 1914) \\
\hline Pilgerhaus (= Weinheim) & Germany & Rheinland-Pfalz R.-S/SE Mainz-n. Weinheim & A. latifrons (Soergel, 1914; Heller, 1962) \\
\hline Stuttgart-Rosenstein & Germany & Baden-Württemberg R.-Stuttgart & A. latifrons (Kahlke, 1975b) \\
\hline Randersacker & Germany & Bayern R.-NW München-n. Würzburg & Alces sp. (Kahlke, 1975b; Koenigswald and Heinrich, 1999) \\
\hline Rabutz & Germany & Sachsen-Anhalt R.-n. Halle & Alces cf. palmatus (Soergel, 1920, fide Koenigswald and Heinrich, 1999) \\
\hline Chlum 4 & Czech Republic & Central Bohemia R.-Středočeský P.-SW Praga-n. Beroun & A. latifrons (Fejfar, 1961; Koenigswald and Heinrich, 1999) \\
\hline Koněprusy (= Zlaty Kun) C718 & Czech Republic & Central Bohemia R.-Středočeský P.-SW Praha-n. Beroun & A. latifrons (Fejfar, 1961; Koenigswald and Heinrich, 1999) \\
\hline Cerveny lom & Czech Republic & Central Bohemia R.-Středočeský P.-SW Praha-n. Suchomasty & A. latifrons (Fejfar, 1961; Koenigswald and Heinrich, 1999) \\
\hline Kozi Grzbiet & Poland & Kielce Voivodate-W Kielce-Zajączków n. Kielce & A. latifrons (Nadachowski, 1989) \\
\hline Gombasek & Slovakia & Eastern Slovakia R.-Východoslovenský P.-W Košice-n. Rožňava & A. latifrons (Fejfar, 1961; Koenigswald and Heinrich, 1999) \\
\hline Rotbav-Dealul Tiganilor u.1.-1 & Romania & Braşov County-n. Braşov-Baraolt Basin & Cervalces latifrons (Rădulescu \& Samson, 1985) \\
\hline Bliznij Hutor & Moldova & Bessarabya-SE Chishinev-Tiraspol-Dniester Basin & A. latifrons (Kahlke, 1990) \\
\hline Malaesty (= Komarova balka) & Moldova & Bessarabya-NW Chishinev-n. Braneshty & A. latifrons (David, 1982; Kahlke, 1990) \\
\hline Sukleja ( = Prosanaa balka) & Moldova & Bessarabya-SE Chishinev-Tiraspol-Dniester Basin & A. latifrons (David, 1982; Kahlke, 1990) \\
\hline Nagornoe 2 & Ukraine & Odesskaya P.-SW Odessa-20 km W Izmaïl-Danube Basin & C. latifrons (Wiegank, 1983) \\
\hline Petropawlowsk & Kazakhstan & northern Kazakhstan-Ishim River & A. latifrons (Kahlke, 1969) \\
\hline Ishim River, Tobolsk Suite & Russia & Western Siberia & A. latifrons (Vangengeim \& Sher, 1970; Kahlke, 1990) \\
\hline Tobolsk (2 locs.) & Russia & Western Siberia-n. Tobolsk-Irtysh River Basin & A. latifrons (Kahlke, 1969) \\
\hline Skorodum & Russia & Western Siberia-Irtysh River-n. the confluence with Ob' River & A. latifrons (Vangengeim, 1977; Kahlke, 1990) \\
\hline Kuschkurgan & Kazakhstan & Southern Kazakhstan-Syr Darya River Basin & A. latifrons (Kahlke, 1990) \\
\hline Om River & Russia & Western Siberia-E/NE Omsk-Irtysh River Basin & A. latifrons (Vangengeim \& Sher, 1970; Kahlke, 1990) \\
\hline Krasnojarka & Kazakhstan & Western Siberia-n. Pavlodar & A. latifrons (Kahlke, 1969) \\
\hline Leninogorsk & Kazakhstan & Eastern Kazakhstan-n. Ust-Kamenogorsk-Irtysh River & A. latifrons (Kahlke, 1990) \\
\hline Zyrjanovsk & Kazakhstan & Eastern Kazakhstan-n. Ust-Kamenogorsk-Irtysh River & A. latifrons (Kozhamkulova, 1974; Kahlke, 1990) \\
\hline Krivosheinskij jar & Russia & Central Siberia-Tomskoj P.-NW Tomsk-n. Krivosheiko-Ob' River & C. latifrons (Shpanskij, 2003) \\
\hline Urtam & Russia & Central Siberia-Tomskoj P.-SW Tomsk-Ob' River & Cervalces cf. latifrons (Shpanskij, 2003) \\
\hline Nakanno & Russia & Central Siberia-Lower Tungusk River & A. latifrons (Kahlke, 1990) \\
\hline Vilyui River (=Vilyuj-Chebyda) & Russia & Central Siberia-E Vilyuisk-tributary of Lena River & A. latifrons (Kahlke, 1990) \\
\hline Omoloj River, loc. E'miche & Russia & north of Eastern Siberia & A. latifrons (Kahlke, 1990) \\
\hline Kyra-Sular & Russia & Central Siberia-Jana River Basin-Adycha River & A. latifrons (Kahlke, 1990) \\
\hline Keremesit River & Russia & Eastern Siberia-n. Allaikha-Indigirka River Basin & A. latifrons (Kahlke, 1990) \\
\hline Alazhea River (2 locs.) & Russia & north of Central Siberia-Kolymskaja Nizmennost' & A. latifrons (Kahlke, 1990) \\
\hline Krestovka River & Russia & Eastern Siberia-Kolyma River & Cervalces sp. (Sher, 1986; Kahlke, 1990) \\
\hline Kzyl-Chilik & Russia & Urali-Cheljabinsk district & A. latifrons (Alekseeva, 1977) \\
\hline
\end{tabular}

Abbreviations as in Table A1. 


\section{Acknowledgements}

We are very grateful to the directors and staffs of many museums and collections (listed in Section 3) visited by Breda. For the useful discussions and suggestions about Alceini, we wish to thank Dr. Adrian M. Lister (University College London), Dr. Andrey V. Sher (Russian Academy of Sciences), Dr. Hans-Dietrich and Ralf-Dietrich Kahlke (Forschungsinstitut Senckenberg für Quartärpaläontologie, Weimar). We thank Dr. Pfeiffer (Cremlingen, Germany) and an anonymous referee for the precious comments on manuscript during refereeing.

Many thanks are due to Dr. Alexej Tesakov and Prof. Eleonora Vangengeim (Geological Institute, Russian Academy of Sciences, Moscow) for providing us a large part of the bibliography on the Siberian localities, to Mr. Dick Mol (Hoofddorp, The Netherlands) for information on the Györújfalu and North Sea material, to Dr. Antonio Tagliacozzo (Pigorini Museum, Roma) for information on the Grotta Maggiore di San Bernardino, to Prof. Benedetto Sala (University of Ferrara), for allowing us to use his extensive bibliography, and to Dr. Evelyn Kustatcher (University of Ferrara), for the help given in reading the German papers. The English text has been corrected by Dr. Krisztina Vasarhelyi (Vancouver, Canada).

\section{References}

Alberdi, M.T., Ortiz-Jaureguizar, E., Prado, J.L., 1998. A quantitative review of European stenonid horses. Paleontology 72 (2), 371-387.

Aleksandrova, L.P., 1976. Rodents of anthropogene of the European part of the USSR. Transactions of the Geological Institute of Academy of Sciences of the USSR 291, 1-98 (in Russian).

Alekseeva, L.I., 1977. Early anthropogene theriofauna of East Europe. Transactions of the Academy of Sciences of the USSR 300, 1-214 (in Russian).

Alexeeva, N.V., Erbajeva, M.A., Sen, S., 2001. Geology and fauna, and preliminary correlation of sediments of the main Late Cenozoic sites of the Transbaikal area. Quaternary International 80/81, 93-100.

Ambrosetti, P., Cremaschi, M., 1976. Segnalazione di una fauna villafranchiana superiore con Libralces gallicus nei livelli fluviolacustri soprastanti alle faune calabriane ad Arctica islandica nei dintorni di Reggio Emilia. Bollettino della Societá Geologica Italiana 94, 1361-1374.

Apostol, L., 1972. Les mammifères pléistocènes de la zone de Prundu, district d'Ilfov. Travaux du Museum d'Histoire Naturelle "Grigore Antipa" 12, 427-438.

Azzaroli, A., 1952. L'alce a Senèze. Palaeontographia Italica 47, 133-141 Tavv. 15-16.

Azzaroli, A., 1953. The deer of the Weybourn Crag and Forest Bed of Norfolk. Bullettin of the British Museum (Natural History), Geology 2 (1), 1-96.

Azzaroli, A., 1979. On the occurrence of the Cervid genus Libralces in the Pleistocene of Italy. Palaeontographia Italica 71, 48-54 Pls. 21-22.
Azzaroli, A., 1982. On the Quaternary and recent cervid genera Alces, Cervalces, Libralces. Bollettino della Societá Paleontologica Italiana 20 (2), 147-154.

Azzaroli, A., 1985. Taxonomy of Quaternary Alcini (Cervidae, Mammalia). Acta Zoologica Fennica 170, 179-180.

Azzaroli, A., 1994. Forest Bed elks and giant deer revisited. Zoological Journal of the Linnean Society 112, 119-133.

Azzaroli, A., De Giuli, C., Ficcarelli, G., Torre, D., 1988. Late Pliocene to early Mid-Pleistocene mammals in Eurasia: faunal succession and dispersal events. Palaeogeography, Palaeoclimatology, Palaeoecology 66, 77-100.

Bajgusheva, V.S., Titov, V.V., Tesakov, A.S., 2001. The sequence of Plio-Pleistocene mammal faunas from the south Russian Plain (the Azov Region). Bollettino della Societá Paleontolologica Italiana 40 (2), 133-138.

Battaglia, M., 1961. La torbiera di Val Martignon. Ricerche geologicomorfologiche e paleontologiche. Tesi di Laurea in Scienze Naturali, Universitá degli Studi di Padova, AA 1960-61, 71 pp., Figg.

Biquand, D., Dubar, M., Sémah, F., 1990. Paleomagnetic correlation of the Mediterranean Upper Neogene biochronology and Villafranchian Vertebrate sites of the Massif Central, France. Quaternary Research 33, 241-252.

Bittmann, F., Müller, H., 1996. The Kärlich Interglacial site and its correlation with the Bilshausen sequence. In: Turner, C. (Ed.), The Early Middle Pleistocene in Europe. Balkema, Rotterdam, pp. 187-193.

Boeskorov, G.G., 2001. The systematics and origin of the modern moose. Vislobokova, I.A. (Editor in chief), Academy of Sciences of the Sakha (Yakutia) Republic, 120pp., Novosibirsk (in Russian).

Boeskorov, G.G., 2002. Taxonomic position of Alces latifrons postremus and Relationships of the Genera Cervalces and Alces (Alcinae, Artiodactyla, Mammalia). Paleontological Journal 36 (6), 660-667.

Boeuf, O., 1997. À propos de Chilhac, Senèze, Blassac-la-Girondie (Haute-Loire, France), gisements du Pliocène terminal, leur intérêt biochronologique. In: Aguilar, J.-P., Legendre, S., Michaux, J. (Eds.), Actes du Congrès BiochroM'97, Mémoires et Traveaux Ecole Pratique des Hautes Etudes, Institut de Montpellier, 21, pp. 661-668.

Boeuf, O., Geraads, D., Guth, C., 1992. Cervidés villafranchiens de Blassac-la-Girondie (Haute-Loire, France). Annales de Paléontologie 78 (3), 159-187.

Bourdier, F., 1961. Le bassin du Rhone au Quaternaire. Géologie et préhistoire. Tome 1: texte. Éditions du Centre National de la Rechèrche Scientifique, 364pp.

Bout, P., 1972. Absolute ages of some volcanic formations in the Auvergne and Velay areas and chronology of the European Pleistocene. In: Nikiforova, K.V. (Ed.), Geology and Fauna of the Lower and Middle Pleistocene of Europe. Academy of Sciences of the USSR, Moscow, pp. 7-24 (in Russian).

Breda, M., 2001a. The holotype of Cervalces gallicus (Azzaroli, 1952) from Senèze (Haute-Loire, France) with nomenclatural implications and taxonomical-phylogenetic accounts. Rivista Italiana di Paleontologia e Stratigrafia 107 (3), 439-449.

Breda, M., 2001b. Gli Alcini fossili europei. Revisione tassonomica, analisi morfologica, valore paleoecologico, distribuzione geografica e temporale. Dottorato di Ricerca in Scienze della Terra, Ciclo XIV, Università degli Studi di Padova, 131pp., 4 Appendici.

Breda, M., 2001c. Alces alces (Linnaeus, 1758) del Pleistocene superiore e dell'Olocene antico in Italia Nord-Orientale. Bollettino del Museo Civico di Storia Naturale di Verona 25 (Geologia, Paleontologia e Preistoria), pp. 27-39.

Breda, M., 2002. The fossil Alcini from Lombardy and Emilia Romagna (North Italy). Memorie di Scienze Geologiche 54, 51-63. 
Breda, M., 2004. The morphological distinction between the postcranial skeleton of Cervalces/Alces and Megaloceros giganteus (Blumenbach, 1799) and comparison between the two Alcini genuses from the Upper Pliocene-Holocene of Western Europe. Geobios, in press.

Breda, M., Marchetti, M., 2003. I mammiferi fossili. In: Ravazzi, C. (Ed.), "Gli antichi bacini lacustri e i fossili di Leffe, Ranica e Pianico-Sèllere (Prealpi Lombarde)". Quaderni di Geodinamica Alpina e Quaternaria - Quaderni della Comunità Montana Valle Seriana, 176pp., Bergamo.

Breda, M., Pini, R., Ravazzi, C., 2004. The palaeoenvironment of Cervalces latifrons (Johnson, 1874) from Fornaci di Ranica (late Early Pleistocene, Northern Italy). Palaeogeography, Palaeoclimatology, Palaeoecology, in press.

Brüning, H., 1978. Zur untergliederung der Mosbacher terrassenabfolge und zum klimatischen Stellenwert der Mosbacher tierwert im rahmen des Cromer-Komplexes. Mainzer Naturwissenschaft Archiv 16, 143-190.

Bubenik, A.B., 1998. Evolution Taxonomy and Morphophysiology. In: Franzmann, A.W., Schwartz, C.C. (Eds.), Ecology and Management of the North American Moose. Smithsonian Institution Press, Washington and London, pp. $77-123$.

Carls, N., Groiss, J.T., Rabeder, G., 1988. Die mittelpleistozäne Höhlenfüllung von Hunas, Fränkische Alb. Chronologische und paläoklimatologische Ergebnisse. Beiträge zur Paläontologie von Österreich 14, 239-249.

Cassoli, P.F., Tagliacozzo, A., 1994. I resti ossei di macromammiferi, uccelli e pesci della Grotta Maggiore di San Bernardino sui Colli Berici (VI): considerazioni paleoeconomiche, paleoecologiche e cronologiche. Bollettino di Paletnologia Italiana $85,1-71$.

Chaix, L., Desse, J., 1981. Contribution à la connaissance de l'Elan (Alces alces, L.) postglaciaire du Jura et du Plateau suisse - Corpus de mesures. Quartär, Jahrbuch Erforsh. Einzeit und Steinzeit 31/ 32, 139-190.

Chlachula, J., 2001. Pleistocene climate change, natural environments and palaeolithic occupation of the Altai area, west-central Siberia. Quaternary International 80/81, 131-167.

Chlachula, J., 2003. The Siberian loess record and its significance for reconstruction of Pleistocene climate change in north-central Asia. Quaternary Science Reviews 22, 1879-1906.

Churcher, C.S., 1991. The status of Giraffa nebrascensis, the synonymies of Cervalces and Cervus, and additional records of Cervalces scotti. Journal of Vertebrate Paleontology 11 (3), 391-397.

Churcher, C.S., Pinsof, D., 1987. Variation in the antler of North American Cervalces (Mammalia; Cervidae): review of new and previously recorded specimens. Journal of Vertebrate Paleontology 7 (4), 373-397.

Clot, A., Chaline, J., Heintz, E., Jammot, D., Mourer-Chauviré, C., Rage, J.C., 1976. Montoussé 5 (Hautes-Pyrénées), un nouveau remplissage de fissure a faune de Vertebrés du Pléistocène inférieur. Géobios 9 (4), 511-514.

Crégut-Bonnoure, E., 1992. Dynamics of bovid migration in Western Europe during the Middle and Late Pleistocene. Courier Forschungs-Institut Senckenberg 153, 177-185.

Crégut-Bonnoure, E., Spassov, N., 2002. Hemitragus orientalis nov. sp. (Mammalia, Bovidae, Caprinae), un nouveau taxon d'Europe orientale. Revue de Paléobiologie 21 (2), 553-573.

Cronin, M.A., Stuart, R., Pierson, B.J., Patton, J.C., 1996. $k$-casein gene phylogeny of higher ruminants (Pecora, Artiodactyla). Molecular Phylogenetics and Evolution 6, 295-311.

Czyżewska, T., 1989. Parzystokopytne-Artiodactyla. Folia Quaternaria 59/60, 209-217 (in Polish).
Danukalova, G.A., Yakovlev, A.G., 2001. Finds of Proboscidean remains in the territory of the Southern Urals region. In: Cavarretta, G., Gioia, P., Mussi, M., Palombo, M.R. (Eds.), "La Terra degli Elefanti", Atti del $1^{\circ}$ Congresso Internazionale, Roma, 16-20 ottobre 2001, Roma, pp. 201-204.

David, A.I., 1982. Localities and species composition of the Tiraspolian theriocomplex in the territory of Moldavia. In: Nigodaev-Nikonov, K.N. (Ed.), Problems of Anthropogene of Moldavia. Academy of Sciences of the Moldavian SSR, Shtiinca Publishing House, Kishinev, pp. 87-96 (in Russian).

Dawkins, W.B., 1887. The British Pleistocene Mammalia (part. VI, Cervidae). Monograph, Palaeontographical Society 40, 1-29 Pls. 1-7.

Delafond, F., Depéret, Ch., 1893. Les terrains tertiaires de la Bresse et leurs gîtes de lignites et de minerais de fer. Imprimerie National, Paris, 332pp.

Desbrosse, R., Pratt, F., 1974. L'Elan Magdalénian de Pierre-Châtel (Ain). Quärtar 25, 143-157 Pls. 12-16

Di Stefano, G., Petronio, C., 1992. Nuove osservazioni su Cervus elaphus acoronatus Beninde del Pleistocene europeo. Bollettino della Società Paleontolologica Italiana 31 (3), 295-315.

Dubrovo, I.A., Kapelist, K.V., 1979. Catalogue of the Tertiary USSR vertebrate localities. Academy of Sciences of the USSR, 158pp., Moscow (in Russian).

Ehrlich, A., 1968. Les diatomées fossiles de sediments villafranchiens de Senèze (Haute-Loire), Massif Central français. Bulletin de l'Association française pour l'étude du Quaternaire 5, 267-280.

Erbajeva, M.A., Alexeeva, N.V., 2000. Pliocene and Pleistocene biostratigraphic succession of Transbaikalia with emphasis on small mammals. Quaternary International 68/71, 67-75.

Erdbrink, D.P., 1954. On one of the oldest known remains of the common elk, Alces alces L., found recently in the Netherlands. Geologie en Mijnbouw, New Series 16, 301-309.

Fejfar, O., 1961. Review of Quaternary Vertebrata of Czechoslovakia. Instytut Geologiczny Prace, Warszawa 34 (1961), 109-118.

Fejfar, O., Heinrich, W.-D., Pevzner, M.A., Lindsay, E.H., 1998. Updating the Neogene Rodent biochronology in Europe. Mededelingen Nederlands Instituut voor Toegepaste Geowetenschappen TNO 60, 533-553.

Ferretti, M.P., 1997. Gli elefanti del Plio-Pleistocene dell'Italia. Tesi di Dottorato di Ricerca in Paleontologia, Università consorziate: Modena, Bologna, Firenze, Roma, 118pp., Tavv (unpublished).

Foronova, I.V., 1998. Early Quaternary mammals from the Kuznetsk Basin, south of western Siberia. Mededelingen Nederlands Instituut voor Toegepaste Geowetenschappen TNO 60, 353-374.

Foronova, I.V., 1999. Quaternary mammals and stratigraphy of the Kuznetsk Basin (South-western Siberia). Antropozoikum 23, 71-97.

Foronova, I.V., 2001a. Quaternary mammals of the south-east of Western Siberia (Kuznetsk Basin): phylogeny, biostratigraphy, and paleoecology. Kanygin A.V. (Editor in Chief), Publishing House of SB RAS, Branch "geo", 243pp., Novosibirsk (in Russian).

Foronova, I.V., 2001b. History of Quaternary Proboscideans of the South of Western Siberia inferred from dental system analysis. In: Cavarretta, G., Gioia, P., Mussi, M., Palombo, M.R. (Eds.), "La Terra degli Elefanti", Atti del $1^{\circ}$ Congresso Internazionale, Roma, 16-20 ottobre 2001, Roma, pp. 109-114.

Forsten, A., 1998. The fossil horses (Equidae, Mammalia) from the Plio-Pleistocene of Liventsovka near Rostov-Don, Russia. Géobios 31 (5), 645-657.

Forsten, A., Sharapov, S., 2000. Fossil equids (Mammalia, Equidae) from the Neogene and Pleistocene of Tadzhikistan. Geodiversitas 22 (2), 293-314.

Fortelius, M., Mazza, P., Sala, B., 1993. Stephanorhinus (Mammalia: Rhinocerotidae) of the western European Pleistocene, with a 
revision of S. etruscus (Falconer, 1868). Palaeontographia Italica $80,63-155$.

Franzen, J.L., Gliozzi, E., Jellinek, T., Scholger, R., Weidenfeller, M., 2000. Die spätaltpleistozäne Fossillagerstätte Dorn-Dürkheim 3 und ihre Bedeutung für die Rekonstruktion der Entwicklung des rheinischen Flusssystems. Senckenbergiana Lethaea 80 (1), 305-353.

Freudenberg, W., 1914. Die Säugetiere des Älteren Quartärs von Mitteleuropa. Geologische und Palaontologische Abhandlungen, N.S. $12(4 / 5), 453-671$.

Friant, M., 1951. Les elephants fossiles de l'Europe Occidentale. Caractères anatomiques. Importance stratigraphique. Atti della Accademia delle Scienze di Ferrara 28, 1-9.

Geist, V., 1999. Deer of the World. Stackpole Books, , Mechanicsburg, USA, 432pp.

Geraads, D., 1983. Les artiodactyles (Mammalia, Artiodactyla) du Pléistocène moyen de Vergranne (Doubs). Annales Scientifiques de l'Université de Besançon, Géologie, 4ème série 5, 69-81.

Geraads, D., 1990. Contribution des Cervidés à la chronologie des débuts de l'occupation humaine en Europe Occidentale. Quaternaire $3 / 4,167-174$.

Gervais, P., 1867-69. Zoologie et Paléontologie générales. Nouvelles recherches sur les animaux vertébrés vivants et fossiles. Première série. Arthus Bertrand, 263pp., 50 plates, Paris.

Gibbard, P.L., West, R.G., Zagwijn, W.H., Balson, P.S., Burger, A.W., Funnell, B.M., Jeffery, D.H., Jong, J. de, Kolfschoten, T. van, Lister, A.M., Meijer, T., Norton, P.E.P., Preece, R.C., Rose, J., Stuart, A.J., Whiteman, C.A., Zalasiewicz, J.A., 1991. Early and early Middle Pleistocene correlations in the southern North Sea Basin. Quaternary Science Reviews 10, 23-52.

Gliozzi, E., Abbazzi, L., Argenti, P., Azzaroli, A., Caloi, L., Capasso Barbato, L., Di Stefano, G., Esu, D., Ficcarelli, G., Girotti, O., Kotsakis, T., Masini, F., Mazza, P., Mezzabotta, C., Palombo, M.R., Petronio, C., Rook, L., Sala, B., Sardella, R., Zanalda, E., Torre, D., 1997. Biochronology of selected Mammals, Molluscs and Ostracods from the Middle Pliocene to the late Pleistocene in Italy. The state of the art. Rivista Italiana di Paleontologia e Stratigrafia 103 (3), 369-388.

Godina, A.A., 1979. The historical evolution of the giraffe genus Palaeotragus. Akademija Nauk SSSR, Trudy Paleontologicheskij Institut, 177pp., Moscow (in Russian).

Guérin, C., 1980. Les rhinocéros (Mammalia, Perissodactyla) du Miocène terminal au Pléistocène supérieur en Europe occidental. Comparaison avec les espèces actuelles. Documents des Laboratoires de Géologie de la Faculté des Sciences de Lyon 79, notes et mémoires, 1-1185.

Guérin, C., Dewolf, Y., Lautridou, J.-P., 2003. Révision d'un site paléontologique célèbre: Saint-Prest (Chartres, France). Geobios $36,55-82$.

Gunn, J., 1891. The Cromer Forest bed and its fossil Mammalia. In: Woodward, H.B., Newton, E.T. (Eds.), Memorials of John Gunn, Norwich, 120pp., 13 Pls.

Harčár, J., Schmidt, Z., 1965. Kvatér v okoli Strekova na Hronskey pahorkatine. Geologicjé Pràce Spràvy 34, 143-151 (in Slovak).

Heintz, E., Guérin, C., Martin, R., Prat, F., 1974. Principaux gisements villafranchiens de France: listes fauniques et biostratigraphie. In: Ve Congrès du Néogène Méditerranéen, Lyon, Septembre 1971, Mémoires du Bureau de Recherches Géologiques et Minieres 78(1), 169-182.

Heintz, E., Poplin, F., 1981. Alces carnutorum (Laugel, 1862) du Pléistocène de Saint-Prest (France). Systématique et évolution des Alcinés (Cervidae, Mammalia). Quartärpaläontologie 4, 105-122.

Heller, F., 1962. Zwei altquartäre Kleinsäugerfaunen aus dem Oberrheingebiet: Hohensülzen bei Worms/Rheinhessen und Pilgerhaus bei Weinheim an der Bergstraße/Baden. Mitteilungen aus dem Geologischen Staatinstitut Hamburg 31, 461-489.
Heller, F., Freund, G., 1983. Die Hohlenruine Hunas bei Hartmannshof (Landkreis Nurberger Land. Quartär-Bibliothek 4, 1-407.

Hennig, E., 1952. Über Säugerfunde aus den Goldshöfer Sanden, Württemberg. Neues Jahrbuch für Geologie und Paläontologie 1952, 126-140.

Hír, J., 1996. Cricetinus janossyi sp. n. (Rodentia, Mammalia) rom the Pliocene fauna of Osztramos 7 (N Hungary). Fragmenta Mineralogica et Palaeontologica 18, 79-90.

Holec, P., 1996. A Plio-Pleistocene large mammal fauna from Strekov and Nová Vieska, south Slovakia. Acta Zoologica Cracoviensia 39 (1), 219-222.

Jnossy, D., 1969. Stratigraphische Auswertung der europäischen mittelpleistozänen Wirbeltierfauna. Teil 2. Berichte der deutschen Geselschaft für geologische Wissenschaft, A. Geologie und Paläontologie 14 (4), 573-643.

Jánossy, D., 1986. Pleistocene vertebrate faunas of Hungary. Developments in Palaeontology and Stratigraphy 8, 1-208.

Jánossy, D., Krolopp, E., 1994. Lower Pleistocene mollusc and vertebrate fauna from the gravel pit of Györújfalu (NW Hungary). Földtani Közlöny 124 (4), 403-440.

Johnson, R., 1874. Notice of a new species of Deer from the Norfolk Forest Bed. Annales and Magazine of Natural History, London 13 (4), 1-4.

Kahlke, H.-D., 1956-1959. Die Cerviden-Reste aus den Altpleistozänen Ilmkiesen von Süssenborn bei Weimar. Abhandlungen der Deutschen Akademie der Wissenschaften zu Berlin. AkademieVerlag Berlin, Teil 1, 1-62, Abb. 1-38., Taf. 1-31; Teil 2, 1-44, Abb. 1-70., Taf. 1-38; Teil 3, 1-45, Abb. 1-25., Taf. 1-35.

Kahlke, H.-D., 1958. Die Cerviden-Reste aus den Altpleistozänen tonen von Voigtstedt bei Sangerhausen. Abhandlungen der Deutschen Akademie der Wissenschaften zu Berlin 1, 10-13.

Kahlke, H.-D., 1960. Die Cerviden-Reste aus den altpleistozänen Sanden von Mosbach (Biebrich-Wiesbaden), teil 1, Die Gewerhe, Gehorne und Gebisse. Abhandlungen der Deutschen Akademie der Wissenschaften zu Berlin 7 (1959), 1-75 Abb. 58, Taf. 1-20.

Kahlke, H.-D., 1961. Revision der Säugetierfaunen der klassisken deutschen Pleistozän-Fundstellen von Süssenborn, Mosbach und Taubach. Geologie 10 (4/5), 373-596.

Kahlke, H.-D., 1965. Die Cerviden-Reste aus den Tonen von Voigtstedt in Thüringen. Paläontogische Abhandlungen, A 2 (2/ 3), 381-426 Taf. 13-32.

Kahlke, H.-D., 1969. Die Cerviden-Reste aus den Kiesen von Süßenborn bei Weimar. Paläontogische Abhandlungen, A 3 (3/4), 547-610 Taf. 27-36.

Kahlke, H.-D., 1971. Fam. Cervidae. In: Nikiforova, K.V. (Ed.), Pleistocene of Tiraspol. Academy of Sciences of USSR, Kishinev, pp. 137-156.

Kahlke, R.-D., 1972. Die Cerviden-Reste aus der Stránska Skála bei Brno. Studia Musei Moraviae-Anthropos 20 (N.S. 12), 193-197.

Kahlke, H.-D., 1975a. Die Cerviden-Reste aus den Travertinen von Weimar-Ehringsdorf. (III ${ }^{\circ}$ Internat. Palaont. Kolloq.), Abhandlungen des Zentralen Geologischen Instituts. Paläontologie 23, 201-249.

Kahlke, H.-D., 1975b. The macro-faunas of continental Europe during the Middle Pleistocene: stratigraphic sequence and problems of intercorrelation. In: Butzer, K.W., Isaac, G.L. (Eds.), After the Australopithecines. Mouton, La Haye, pp. 309-374.

Kahlke, H.-D., 1976. Die Cervidenreste aus den Travertinen von Taubach. Quartärpaläontologie 2, 209-223.

Kahlke, H.-D., 1990. On the evolution, distribution and taxonomy of fossil elk/moose. Quartärpaläontologie 8, 83-106.

Kahlke, H.-D., 1995. Ein fossiler Elch-Fund aus dem Unterpleistozän von Untermaßfeld in Thüringen (Mitteldeutschland). Quartär 45/ 46, 227-235.

Kahlke, H.-D., 1997. Die Cerviden-Reste aus dem Unterpleistozänen von Untermassfeld. In: Kahlke R.-D., Das Pleistozän von (Eds.), 
Untermassfeld bei Meiningen (Thüringen), Monographien des Römisch-Germanischen Zentralmuseums Mainz 40(1), 181-275.

Kahlke, R.-D., 1999. The History of the Origin, Evolution and Dispersal of the Late Pleistocene Mammuthus-Coelodonta Faunal Complex in Eurasia (Large Mammals). Mammoth Site of Hot Springs, SD, Special Papers, Fenske Companies 219pp., Rapid City.

Kahlke, R.-D., 2000. The Early Pleistocene (Epivillafranchian) faunal site of Untermassfeld (Thuringia, Central Germany). Synthesis of new results. In: Lordkipanidze, D., Bar-Yosef, O., Otte, M. (Eds.), Proceedings of the first international symposium, Dmanisi, Tbilisi (Georgia) September 1998, Études et Recherches Archéologiques de l'Université de Liège 92, pp. 123-138.

Kahlke, R.-D., 2001a. Die Unterpleistozäne Komplexfundstelle Untermassfeld-Zusammenfassung des Kenntnisstandes sowie Synthetische Betrachtungen zu Genesemodell, Paläoökologie und Stratigraphie. In: Kahlke, R.-D., (Eds.), Das Pleistozän von Untermassfeld bei Meiningen (Thüringen), Monographien des Römisch-Germanischen Zentralmuseums Mainz 40(3), pp. 931-1030.

Kahlke, R.-D., 2001b. Ein Meer voller Knochen? Pleistozäne Wirbeltierreste aus der Scheldemündung und vom Nordseeboden. Natur und Museum 131 (12), 417-432.

Keller, T., 2004. Sedimentology and taphonomy of the Middle Pleistocene Mosbach Sands (Germany). In: Maul, L.C., Kahlke, R.-D. (Eds.), 18th International Senckenberg Conference, VI International Palaeontological Colloquium in Weimar-"Late Neogene and Quaternary biodiversity and evolution: Regional developments and interregional correlations"- Weimar (Germany), 25th-30th April, 2004-Conference Volume. Terra Nostra, 2004(2), pp. 131-132.

Koenigswald, W. von, 1995. Mammal traverse. Quaternary vertebrate faunas in Central Europe. In: Schirmer, W. (Ed.), Quaternary Field Trips in Central Europe. INQUA, pp. 707-746.

Koenigswald, W. von, Heinrich, W.-D., 1999. Mittelpleistozäne Säugetierfaunen aus Mitteleuropa-der Versuch einer biostratigraphischen Zuordnung. Kaupia, Darmstädter Beiträge zur Naturgeschichte 9, 53-112.

Koenigswald, W. von, Menger, F., 1997. Mögliches Auftreten von Trogontherium cuvieri und Alces latifrons im letzen Interglazial der nördlichen Oberrheinebene. Cranium 14 (1), 2-10.

Koenigswald, W. von, Tobien, H., 1987. Bemerkungen zur Altersstellung der pleistozänen Mosbach-Sande bei Wiesbaden. Geologische Abhandlungen Hessen 115, 227-237.

Kolfschoten, T. van, 2001. Pleistocene Mammals from the Netherlands. Bollettino della Società Paleontologica Italiana 40 (2), 209-215.

Kolfschoten, T. van, Gibbard, P.L., 1998. The Dawn of the Quaternary: an introduction. Mededelingen Nederlands Instituut voor Toegepaste Geowetenschappen TNO 60, 13-17.

Koufos, G.D., 2001. The Villafranchian mammalian faunas and biochronology of Greece. Bollettino della Società Paleontologica Italiana 40 (2), 217-223.

Kozhamkulova, B.S., 1974. A broad-forehead elk, Alces latifrons, in Transbaikalia. Teriologiya 2, 89-92 (in Russian).

Kretzoi, M., 1956. A Villányi Hegység Alsó-Pleistocen GerincesFaunái. Geologica Hungarica 27, 1-264.

Kretzoi, M., 1962. Fauna und Faunenhorizont von Csarnóta. Magyar Állami Földtani Intézet Évi Jelent 1959, 344-395.

Kuss, S.E., 1955. Die stratigraphische verteilung der altpleistozänen Fauna aus dem Tonlager von Jockgrim in der Pfalz. Beitrage zur Naturkunde Forschung Südwestdeutschland 14 (2), 93-100.

Laugel, A., 1862. La faune de Saint-Prest, près Chartres (Eure-etLoir). Bulletin de la Société Géologique de France 19 (2), 709-718.
Lehmann, U., 1953. Eine Villafranchiano-fauna von der Erpfingen Höhle (Schwäbische Alb.). Neues Jahrbuch fur Geologie und Paleontologie, Monatsheft 437-464.

Lehmann, U., 1957. Weitere Fossilfunde aus dem ältesten Pleistozän der Erpfingen Höhle (Schwäbische Alb.). Mitteilungen der Geologischen Staatsinstitut Hamburg 26, 60-99.

Lister, A.M., 1984. The fossil record of elk (Alces alces (L.)) in Britain. Quaternary Newsletters 44, 1-7.

Lister, A.M., 1987. Diversity and evolution of antler form in Quaternary deer. In: Wemmer, C.M. (Ed.), Biology and Management of the Cervidae. Smithsonian Institution, Washington, pp. 81-98.

Lister, A.M., 1993a. The stratigraphical significance of deer in the Cromer Forest-Bed Formation. Journal of Quaternary Science 8 (2), 95-108.

Lister, A.M., 1993b. Evolution of mammoths and moose: the Holoartic perspective. In: Martin, R.A., Barnosky, A.D. (Eds.), Morphological Change in Quaternary Mammals of North America. Cambridge University Press, New York, pp. 178-204.

Lister, A.M., 1993c. Patterns of evolution in Quaternary mammal lineages. In: Edwards, D. (Ed.), Patterns and Processes of Evolution. Academic Press, London, pp. 71-93.

Lister, A.M., 1996. The stratigraphical interpretation of large mammal remains from the Cromer Forest-bed Formation. In: Turner, C. (Ed.), The Early Middle Pleistocene in Europe. Balkema, Rotterdam, pp. 25-44.

Lister, A.M., 1998. The age of Early Pleistocene mammal faunas from the "Weybourn Crag" and Cromer Forest-bed Formation (Norfolk, England). Mededelingen Nederlands Instituut voor Toegepaste Geowetenschappen TNO 60, 271-280.

Lister, A.M., 2004. Subspecies differentiation among moose (Alces alces (L.)): geographical variation in cranial morphology. In: Crégut, E. (Ed.), "The holoartic ungulates of the Pliocene and Pleistocene" Proceedings of the International Congress, Avignon (FR), 19-22 September 2000, Quaternaire, in press.

Lister, A.M., Sher, A.V., 2001. The origin and evolution of the woolly mammoth. Science 294, 1094-1097.

Lydekker, R., 1898. The Deer of All Lands: a History of the Family Cervidae, Living and Extinct. Rowland Ward, 329pp., London.

Malez, M., 1986. Die quartären Vertebraten-Faunen in der SFR Jugoslawien. Quartärpaläontologie 6, 101-111.

Marchetti, M., 1998. Insettivori-Mammalia - della fauna bihariana di Monte La Mesa-Verona - nel quadro biocronologico europeo. Tesi di Laurea in Scienze Naturali, Anno Acc. 1997/1998, Università degli Studi di Ferrara, 441pp.

Marcović-Marjanović, J., 1970. Data concerning the stratigraphy and the fauna of the Lower and Middle Pleistocene of Yugoslavia. Palaeogeography, Palaeoclimatology, Palaeoecology 8, 153-163.

Markova, A.K., 1990. Pleistocene microtheriofauna of the European part of the USSR. In: Fejfar, O., Heinrich, W.-D. (Eds.), International Symposium "Evolution, Phylogeny and Biostratigraphy of Arvicolids (Rodentia, Mammalia)", Praha, pp. 313-338.

Martin, R., 1973. Trois nouvelles espèces de Caninae (Canidae, Carnivora) des gisements plio-villafranchiens d'Europe. Documents des Laboratoires de Géologie de la Faculté des Sciences de Lyon 57, 87-96.

Masini, F., Sala, B., Ambrosetti, P., Azzaroli, A., Ficcarelli, G., Kotsakis, T., Rook, L., Torre, D., 1990. Mammalian faunas of selected Villafranchian and Galerian localities. Poster shown at: INQUA SEQS, Cromer Symposium, Norwich, September 1990.

Maul, L., 2000. Die Fossilfundstelle Weimar-Ehringsdorf-Eine Übersicht. Geowissenschaftliche Mitteilungen Thüringen 10, $167-174$. 
Mäuser, M., 1990. Alces latifrons (Johnson, 1874) (Mammalia, Cervidae) von der altpleistozänen Säugetier-Fundstelle Würzburg-Schalksberg (Unterfranken, BRD). Quartärpaläontologie 8, 205-214.

Mayet, L., Roman, F., 1923. Elephas planifrons Falconer des Sables de Chagny et faunes de mammifères d'age villafranchien-SaintPrestian. Annales de l'Université de Lyon 42, 1-87.

Mazza, P., Rustioni, M., 1994. The fossil bear from Senèze (Southern France). Rendiconti Lincei-Scienze Fisiche e Naturali, Accademia Nazionale dei Lincei, Serie IX 5, 17-26.

Meijer, T., Preece, R.C., 1996. Malacological evidence relating to the stratigraphical position of the Cromerian. In: Turner, C. (Ed.), The Early Middle Pleistocene in Europe. Balkema, Rotterdam, pp. 53-82.

Mol, D., 1994. Nog meer nijpaarden uit Nederlandse bodem. Grondboor and Hamer 48 (1), 7-8.

Nadachowski, A., 1989. Rodentia. In: Kowalski, K. (Ed.), History and evolution of the terrestrial fauna of Poland. Folia Quaternaria 59/ 60 , pp. $151-176$.

Newton, E.T, 1882. The Vertebrata of the Forest Bed Series of Norfolk and Suffolk. Memoirs of the Geological Survey of England and Wales 8, 1-143.

Nilsson, T., 1983. The Pleistocene. Geology and Life in the Quaternary Age. D. Reidel Publishing Company, Dordrecht, Holland/Boston, USA/London, England, 651pp.

Nikolskiy, P.A., 1997. Extinct moose in Beringia. Beringia Pleoenvironmental Workshop, September 1997, abstract.

Nikolskiy, P.A., Titov, V.V., 2002. Libralces gallicus (Cervidae, Mammalia) from the Upper Pliocene of the North East Azov Region. Paleontologicheskij Zhurnal 2002 (1), 92-98 (in Russian).

Owen, F.R.S., 1869. Note on the occurrence of remains of the elk (Alces palmatus) in British post-Tertiary deposits. The Geological Magazine 6, 389.

Palombo, M.R., Azanza, B., Alberdi, M.T., 2000-2002. Italian mammal biochronology from the Latest Miocene to the Middle Pleistocene: a multivariate approach. Geologica Romana 36, 335-368.

Pavlow, M., 1906. Etudes sur l'histoire paléontologique des Ongulés Sélénodontes post-tertiaires de la Russie. Mémoires de l'Académie Impériale des Sciences de St.-Pétersbourg, VIII Série, Classe Physico-Mathématique 20(1), pp. 1-95, Pls. 1-8.

Pevzner, M., 1970. Paleomagnetic studies of Pliocene-Quaternary deposits of Pridniestrovie. Palaeogeography, Palaeoclimatology, Palaeoecology 8, 215-219.

Pfeiffer, T., 1999a. Alces latifrons (Johnson 1874) (Cervidae, Mammalia) from Late Pleistocene sediments of the Upper Rhine Valley (West Germany). Neues Jahrbuch für Paläontologie Abhandlungen 211, 291-327.

Pfeiffer, T., 1999b. The Morphological distinction of Limb Bones of Alces latifrons (Johnson 1874) and Megalocerus giganteus (Blumenbach 1799) from Middle- and Late Pleistocene Localities of Germany. Kaupia. Darmstädter Beiträge zur Naturgeschichte 9, $113-126$.

Pfeiffer, T., 2002. The first complete skeleton of Megaloceros verticornis (Dawkins, 1868) Cervidae, Mammalia, from Bilshausen (Lower Saxony, Germany): description and phylogenetic implications. Mitteilungen aus dem Museun fur Naturkunde in Berlin, Geowissenschaftliche Reihe 5, 289-308.

Post, K., Mol, D., Reumer, J., Vos, J. de, Laban, C., 2001. Een zoogdierfauna met twee (?) mammoetsoorten uit het Bavelien van de Noordzeebodem tussen England en Nederland. Grondboor \& Hamer 6, 2-22.

Preece, R.C., 2001. Molluscan evidence for differentiation of interglacials within the 'Cromerian Complex'. Quaternary Science Reviews 20, 1643-1656.
Prevot, M., Dalrymple, G.B., 1970. Un bref épisode de polarité géomagnétique normale au cours de l'époque inverse Matuyama. Comptes Rendus Academie des Sciences de Paris 271, Série D, pp. 2221-2224.

Rădulescu, C., Kovács, A., 1968. Noi contribuţii la cunoaşterea faunei de mamifere fosile din Bazinul Baraolt (Depresiunea Braşov). Lucrările Institutului de Speologie "Emil Racoviţă" 7, 231-253.

Rădulescu, C., Samson, P.-M., 1985. Pliocene and Pleistocene mammalian biostratigraphy in southeastern Transylvania (Romania). Travaux de l'Institut de Spéolologie "Emile Racovitza" 24, 85-95.

Rădulescu, C., Samson, P.-M., 1990. The Plio-Pleistocene mammalian succession of the Olteţ valley, Dacic Basin, Romania. Quartärpaläontologie 8, 225-232.

Rădulescu, C., Samson, P.-M., 2001. Biochronology and evolution of the Early Pliocene to the Early Pleistocene mammalian faunas of Romania. Bollettino della Società Paleontologica Italiana 40 (2), 285-291.

Rădulescu, C., Samson, P.-M., Mihăilă, N., Kováks, A., 1965. Contributions à la connaissance des faunes de Mammifères pléistocènes de la Dépression de Braşov (Roumanie). Eiszeitalter und Gegenwart 16, 132-188.

Rădulescu, C., Samson, P.-M., Ştiucă, E., Enciu, P., Popescu, A., 1993. New fossil mammal associations of the Jiu Valley. A contribution to the Early and early Late Pliocene biostratigraphy of the Dacic Basin, Romania. Travaux de l'Institut de Spéolologie "Emile Racovitza" 32, 95-105.

Rakovec, I., 1954. Libralces aff. gallicus Azzaroli from the Vič terrace near Ljubljana. Sprejeto na seji IV. razreda Slovenske Akademije Znanosti in Umetnosti, dne 13 Februarja 1954, pp. 279-295 (in Slovenian)

Rakovec, I., 1956. The remnants of the elk (Alces alces L.) in Yugoslavia. Annales Géologiques de la Péninsule Balkanique 24, $1-13$ Pl. 1.

Rakovec, I., 1975. Über quärtare Säugetierfaunen Sloweniens (NW Jugoslavien) SAZU,. Acta Archaeologica 24 (1973), 225-270.

Randi, E., Mucci, N., Pierpaoli, M., Douzery, E., 1998. New phylogenetic perspectives on the Cervidae (Artiodactyla) are provided by the mitochondriel cytochrome $b$ gene. Proceedings of the Royal Society of London B 265, 793-801.

Ravazzi, C., Moscariello, A., 1998. Sedimentation, palaeoenvironmental evolution and time duration of earliest Pleistocene climatic cycles in the 24-56 m FM core interval (Leffe Basin, Northern Italy). Mededelingen Nederlands Instituut voor Toegepaste Geowetenschappen TNO 60, 467-490.

Ravazzi, C., Pini, R., Breda, M., Martinetto, E., Muttoni, G., Chiesa, S., Confortini, F., Ramon, E., Malzanni, M., Paganoni, A., 2004. The lacustrine deposits of Fornaci di Ranica (late Early Pleistocene, Italian Pre-Alps): stratigraphy, palaeoenvironment and geological evolution. Quaternary International, in press.

Reichenau, W. von, 1900. Notizien aus den Museum zu Mainz. Neus Jahrbuch für Mineralogie 2, 52-62.

Reumer, J.W.R., Mol, D., Vos, J. de, 2000. Early to Middle Pleistocene faunas from the Netherlands with Bison and Praeovibos. In: The holoarctic Ungulates of the Pliocene and Pleistocene, 19-22, September 2000, Abstracts, Avignon, France.

Roger, S., Coulon, C., Thouveny, N., Feraud, G., Van Velzen, A., Fauquette, S., Cochemé, J.J., Prévot, M., Verosub, K.L., 2000. ${ }^{40} \mathrm{Ar} /{ }^{39} \mathrm{Ar}$ dating of a tephra layer in the Pliocene Senèze maar lacustrine sequence (French Massif Central): constraint on the age of the Réunion-Matuyama transition and implications on paleoenvironmental archives. Earth and Planetary Science Letters 183, $431-440$. 
Rothausen, K., 1970. Praemegaceros Portis, 1920 (Cervidae, Mamm.) als whichtiger stratigraphischer Beleg im Quartär von Kärlich/ Neuwieder Becken (Mittelrhein). Mainzer Naturwissenschaft Archiv 9, 303-317.

Rouiller, C., 1847. Etudes paleontologiques sur les environ de Moscow. Jubileum, 35pp., Pls. 1-5.

Rusanov, B.S., 1968. Biostratigraphy of Cenozoic deposits in Meridional Yakutia. Akademija Nauk SSSR, Moscow, 149pp. (in Russian).

Samson, P.-M., 1975. Les équidés fossiles de Roumanie. Geologica Romana 14, 165-352 Pls. 1-20.

Sardella, R., Abbazzi, L., Argenti, P., Azzaroli, A., Caloi, L., Capasso Barbato, L., Di Stefano, G., Ficcarelli, G., Gliozzi, E., Kotzakis, T., Masini, F., Mazza, P., Mezzabotta, C., Palombo, M.R., Petronio, C., Rook, L., Sala, B., Torre, D., 1998. Mammal faunal turnover in Italy from the Middle Pliocene to the Holocene. Mededelingen Nederlands Instituut voor Toegepaste Geowetenschappen TNO 60, 499-512.

Schäfer, D., Heinrich, W.-D., Böhme, G., Steiner, W., 2004. Aspects of the geology, palaeontology, and archaeology of the travertine site of Weimar-Ehringsdorf (Thuringia, Central Europe). In: Maul, L.C., Kahlke, R.-D. (Eds.), 18th International Senckenberg Conference, VI International Palaeontological Colloquium in Weimar- "Late Neogene and Quaternary biodiversity and evolution: Regional developments and interregional correlations"Weimar (Germany), 25th-30th April, 2004-Conference Volume. Terra Nostra 2004 (2), p. 229.

Schaub, S., 1933. Die Ruminantier des ungarischen Praeglacials. Eclogae Geologicae Helvetiae 25, 319-330.

Schaub, S., 1943. Die oberpliocaene Säugertierfauna von Senèze (Haute-Loire) und ihre verbreitungsgeschichtliche Stellung. Eclogae Geologicae Helvetiae 36 (2), 270-289.

Schlosser, M., 1928. Über Alces latifrons aus einer Schlotausfüllung bei Tuttlingen. Centralblatt für Mineralogie, Geologie und Paläontologie 124-128.

Schmidt, H., 1930. Ein skelett von Alces latifrons aus der Gegend von Göttingen. Palaeontologische Zeitschrift 12, 135.

Schmidt, H., 1934. Ein Skelett von Riesenelch. Forschung und Fortschrifte 10, 198-199.

Schmidt, Z., Halouzk, R., 1970. Nová fauna vertebrát villafranchienu zo Strekova na Hronskey pahorkatine (Podunajská nížina). Geologické Práce 51, 173-183 (in Slovak).

Schüller, T., 2004. ESR dating of a new palaeolithic find layer of the travertine site of Weimar-Ehringsdorf (Central Germany). In: Maul, L.C., Kahlke, R.-D. (Eds.), 18th International Senckenberg Conference, VI International Palaeontological Colloquium in Weimar - "Late Neogene and Quaternary biodiversity and evolution: Regional developments and interregional correlations"Weimar (Germany), 25th-30th April, 2004- Conference Volume. Terra Nostra, 2004 (2), pp. 233-235.

Scott, W.B., 1885. Cervalces americanus, a fossil Moose, or Elk, from the Quaternary of New Jersey. Proceedings of the Academy of Natural Sciences of Philadelphia 37, 181-202.

Shackleton, N.J., 1995. New data on the evolution of Pliocene climatic variability. In: Vrba, E.S., Denton, G.H., Partridge, T.C., Burckle, L.H. (Eds.), Palaeoclimate and Evolution with Emphasis on Human Origins. Yale University Press, Yale, pp. 242-248.

Sher, A.V., 1974. Pleistocene mammals and stratigraphy of the far Northeast USSR and North America. International Geology Review 16 (7), 1-287.

Sher, A.V., 1986. Olyrian land mammal age of Northeastern Siberia. Palaeontographia Italica 74, 97-112 Pls. 1-6.

Sher, A.V., 1987. History and evolution of moose in USSR. In: "Biology and use of Elk", Swedish Wildlife Research, Supplement 1 , pp. 71-97.
Shpanskij, A.V., 2003. Quaternary mammals of Tomsk region and their value in the study of the middle Priobye. 162pp, Tomsk.

Soergel, W., 1914. Die diluvialen Säugetiere Badens. I. Älteres und mittleres Diluvium. Mitteilungs grossherzgl. Badischen Geologischen Landesanstalt 9, 1-254.

Soergel, W., 1920. Der Rabutzer Beckenton. Geologie, Paläontologie, Biologie. Veröffentlichungen Provinzialmuseum Halle 1 (4), 1-35.

Soergel, W., 1925. Die Säugetierfauna des antidiluvialen Tonlagers von Jockgrim in der Pfalz. Zeitschrift der Deutschen Geologischen Gesellschaft 77 (3), 405-438.

Sotnikova, M.V., 1989. Late Pliocene-Early Pleistocene Carnivora: stratigraphic significance. Transactions of the Academy of Sciences of the USSR 140, 1-123 (in Russian).

Sotnikova, M.V., Dodonov, A.E., Pen'kov, A.V., 1997. Upper Cenozoic bio-magnetic stratigraphy of Central Asian mammalian localities. Palaeogeography, Palaeoclimatology, Palaeoecology 133, 243-258.

Sotnikova, M.V., Bajgusheva, V.S., Titov, V.V., 2002. The revision of Khapry faunal complex of carnivora and its stratigraphic significance. Stratigraphy and Geological correlation 10 (4), 62-78 (in Russian).

Spassov, N., Crégut-Bonnoure, É., 1999. Premières données sur les Bovidae Villafranchiens de Bulgarie. Comptes Rendus Academie des Sciences de Paris, Sciences de la terre et des planètes 328, 493-498.

Steinmüller, A., 1972. Die schichtenfolgen von Süßenborn und Voigtstedt und die Gliederung des Mittelpleistozäns. Geologie 21 (2), 149-165.

Stuart, A.J., 1974. Pleistocene history of the British Vertebrate fauna. Biological Review 49, 225-266.

Stuart, A.J., 1981. A comparison of the Middle Pleistocene mammal faunas of Voigtstedt (Thuringia, GDR) and West Runton (Norfolk, England). Quartärpaläontologie 4, 155-163.

Stuart, A.J., 1982. Pleistocene vertebrates in the British Isles. Longman, London, 212pp.

Stuart, A.J., 1996. Vertebrate faunas from the early Middle Pleistocene of East Anglia. In: Turner, C. (Ed.), The early Middle Pleistocene in Europe. Balkema, Rotterdam, pp. 9-24.

Stuart, A.J., Lister, A.M., 2001. The mammalian faunas of Pakefield/ Kessingland and Corton, Suffolk, UK: evidence for a new temperate episode in the British early Middle Pleistocene. Quaternary Science Reviews 20, 1677-1692.

Svistun, V.I., 1988. Lower Pleistocene Alces latifrons Johnson (Artiodactyla) of the southern European part of the USSR. Paleontologicheskiy Sbornik 25, 60-62 (in Russian).

Terzea, E., 1994. Fossiliferous sites and the chronology of mammal faunas at Betfia (Bihor, Romania). Travaux du Museum d'Histoire naturelle "Grigore Antipa" 34, 467-485.

Thies, O., 1926. Beiträge zur Kenntnis der Heppenlochfauna und der Fauna der Frankenbacher Sande. Jahrbuch der Preußischen geologischen Landesanstalt 46, 576-615.

Tobien, H., 1974. Villafranchian mammals in Western Germany. In: Ve Congrès du Néogène Méditerranéen, Lyon, Septembre 1971, Mémoires du Bureau de Recherches Géologiques et Minieres 78(1), 259-265.

Vangengeim, E.A., 1977. Paleontologic foundation of the Anthropogene stratigraphy of Northern Asia (on mammals). X Congress of INQUA (Birmingham, 1977). Publishing House Nauka, Moscow, 169pp (in Russian).

Vangengeim, E.A., Flerow, C.C., 1965. L'élan à front large (Alces latifrons) en Sibérie. Bulletin Commission Etude période Quaternaire Academie Sciences URSS 30, 166-171 (in Russian).

Vangengeim, E.A., Pevzner, M.A., 1991. The Villafranchian of the USSR: bio- and magnetostratigraphy. In: Vangengeim, E.A. (Ed.), Pliocene and Anthropogene palaeogeography and biostratigraphy. Nauka, Moscow, pp. 124-145 (in Russian) 
Vangengeim, E.A., Sher, A.V., 1970. Siberian equivalents of the Tiraspol faunal complex. Palaeogeography, Palaeoclimatology, Palaeoecology 8, 197-207.

Vangengeim, E.A., Belyayeva, Ye.I., Garutt, V.Ye., Dmitriyeva, Ye.L., Zazhigin, V.S., 1966. Eopleistocene mammals of Western Transbaykal. Trudy GIN AN SSSR, 152pp. (in Russian).

Vangengeim, E.A., Sotnikova, M.V., Alekseeva, L.I., Vislobokova, I.A., Zhegallo, V.I., Zazhigin, V.S., Shevyreva, N.S., 1988. Late Pliocene-Early Pleistocene biostratigraphy of Tadjikistan. Academy of Sciences of Russia, Moscow, 126pp. (in Russian).

Vangengeim, E.A., Erbajeva, M.A., Sotnikova, M.V., 1990. Pleistocene mammals from Zasuhino, Western Transbaikalia. Quartärpaläontologie 8, 257-264.

Vereshchagin, N., 1955. L'elan du Caucase (Alces alces caucasicus n. ssp.) et matériaux pour l'historie des élans dans le Caucase. Zoologische Zhurnal 34 (2), 460-463 (in Russian).

Vereshchagin, N.K., 1967a. The geological history of the elk and its relations to the early man. In: Biology and economy of the elk, Rossel'khozizdat, Moskow, pp. 3-37 (in Russian).

Vereshchagin, N., 1967b. The Mammals of the Caucasus, a History of the evolution of the fauna. Academy of Sciences of the USSR, Zoological Institut of Moscow-Leningrad, 704pp. (translated from the 1959 Russian by Israel Program for Scientific Translation, 816pp., Jerusalem).

Vislobokova, I.A., 1980. Deer from the Kuruksai locality. In: Nikiforova, K.V., Dodonov, A.Y. (Eds.), The boundary of the Neogene and the Quaternary system. Moscow, pp. 256-258 (in Russian).

Vislobokova, I.A., 1986. Elks in the Pliocene of the USSR. Quartärpaläontologie 6, 239-242.

Vislobokova, I.A., 1996. The Pliocene Podpusk-Lebyazh'e mammalian faunas and assemblage, Western Siberia. Palaeontographia Italica $83,1-23$.

Vislobokova, I.A., Dmitriyeva, Y.L., Kalmykov, N.P., 1994. On the age of the mammalian fauna of Udunga, Western Transbaikalia. Paleontological Journal 28 (1), 166-172.
Vislobokova, I.A., Dmitriyeva, Y.L., Kalmykov, N.P., 1995. Artiodactyls from the Late Pliocene of Udunga, western Trans-Baikal, Russia. Journal of Vertebrate Paleontology 15 (1), 146-159.

Vörös, I., 1985. Alces brevirostris Kretzoi from the Ördöglyuk Cave at Solimar (Hungary). Fragmenta Mineralogica et Palaeontologica 12, 59-66.

Vos, J. de, Mol, D., 1997. De vonds van de maand: de vondst van een elandstang. Cranium 14 (2), 109-115.

Weiler, W., 1935. Alces latifrons Johns. aus einer Terrasse mit Elephas trogontheri primigenius. Jahresberichte und Mitteilungen des Oberrheinischen geologischen Vereines, Neue Folge 24, 137-139.

Wernert, P., 1957. Stratigraphie, paléontologie et préhistorique des sediments quaternaires d'Alsace, Achenheim. Service de la Carte géologique d'Alsace-Lorraine, Mémoires 14, 254pp.

West, R.G., 1980. The Pre-glacial Pleistocene of the Norfolk and Suffolk Coasts. Cambridge University Press, Cambridge, 203pp.

Wiegank, F., 1983. Beitrag Zur Chronostratigraphie und Entwicklung der Grosssäugerfaunen im jüngeren Känozoikum von Europa auf geochronologischer und magnetostratigraphischer Grundlage. Schriftenreihe der Geologischen Wissenschaft 19/20, 355-380.

Wiegank, F., 1990. Magnetostratigraphisch-geochronologische Untersuchungen zur Geschichte des Plio-Pleistozäns in Mitteleuropa und ihrer Beziehungen zur globalen geologischen, paläoklimatischen und paläoökologischen Entwicklung. Veröffentlichungen des Zentralinstituts für Physik der Erde 113, $1-307$.

Yakhimovic, V.L., 1965. Anthropogen of Southern Urals, Academy of Sciences of the USSR, Bashkirian Branch, Mineralogical and Geological Institute, Moscow, pp. 229-239 (in Russian).

Zagwijn, W.H., 1996. The Cromerian Complex Stage of the Netherlands and correlation with other areas in Europe. In: Turner, C. (Ed.), The early Middle Pleistocene in Europe. Balkema, Rotterdam, pp. 145-172. 